\title{
Connexinopathies: a structural and functional glimpse
}

\author{
Isaac E. García ${ }^{1 \dagger}$, Pavel Prado ${ }^{1 \dagger}$, Amaury Pupo ${ }^{1 \dagger}$, Oscar Jara', Diana Rojas-Gómez, Paula Mujica', \\ Carolina Flores-Muñoz ${ }^{1}$, Jorge González-Casanova' ${ }^{1}$, Carolina Soto-Riveros ${ }^{1}$, Bernardo I. Pinto ${ }^{1}$, Mauricio A. Retamal², \\ Carlos González ${ }^{1}$ and Agustín D. Martínez ${ }^{1 *}$
}

From International Gap Junction Conference 2015

Valparaiso, Chile. 28 March - 2 April 2015

\begin{abstract}
Mutations in human connexin $(C x)$ genes have been related to diseases, which we termed connexinopathies. Such hereditary disorders include nonsyndromic or syndromic deafness (Cx26, Cx30), Charcot Marie Tooth disease (Cx32), occulodentodigital dysplasia and cardiopathies (Cx43), and cataracts (Cx46, Cx50). Despite the clinical phenotypes of connexinopathies have been well documented, their pathogenic molecular determinants remain elusive. The purpose of this work is to identify common/uncommon patterns in channels function among Cx mutations linked to human diseases. To this end, we compiled and discussed the effect of mutations associated to Cx26, Cx32, Cx43, and Cx50 over gap junction channels and hemichannels, highlighting the function of the structural channel domains in which mutations are located and their possible role affecting oligomerization, gating and perm/ selectivity processes.
\end{abstract}

Keywords: Connexins, hemichannels, gap junction channels, structure and function, human genetic disease

\section{Background}

Connexin gap junction channels (GJCs) and hemichannels (HCs) are critical for cellular communication. GJCs allow the intercellular exchange of ions and small molecules (e.g., IP3, cAMP, cGMP, ATP) and diverse metabolites (e.g., sugars, amino acids, glutathione) (reviewed in [1]). The same molecules and ions can pass through $\mathrm{HCs}$, but in this case to take part as autocrine and paracrine signals (reviewed by $[2,3]$ ). Mutations in connexins (Cxs) genes are associated to genetic disorders such as skin abnormalities, cardiopathies, neurodegenerative and developmental diseases, cataracts, and most cases of hereditary deafness (reviewed by [4-6]).

Each $\mathrm{HC}$ is formed by the oligomerization of six Cxs subunits and the end-to-end docking of two HCs forms

\footnotetext{
*Correspondence: agustin.martinez@uv.cl

${ }^{\dagger}$ Equal contributors

${ }^{1}$ Centro Interdisciplinario de Neurociencia de Valparaíso, Instituto de Neurociencia, Facultad de Ciencias, Universidad de Valparaíso, Valparaíso, Chile

Full list of author information is available at the end of the article
}

GJCs. The membrane topology of Cxs includes four transmembrane domains (designated as TM1-TM4) connected by two extracellular loops (ECL) and one intracellular loop (ICL). The amino terminus (NT) and the carboxyl terminus (CT) segments are cytoplasmic (Fig. 1a). Despite Cxs share high homology, there are important differences in the amino acid sequence of the ICL and CT. These segments contain motifs for regulatory kinases and cytoskeletal binding proteins $[7,8]$. Oligomerization between suited isoforms also contributes to the assortment of $\mathrm{Cx}$-based channels; for instances, heteromeric GJCs (HCs constituted by more than one Cxs type) and/or heterotypic channels (two homomeric HCs each made by a different Cxs type). These combinations may produce GJCs with particular functional and regulatory properties. Several works pointed out to TM3 in Cx32 [9-11] and Cx43 [12], and TM1 and NT segments in Cx26 [12, 13] as critical to regulate oligomerization of Cxs. In addition, a salt bridge between residues Glu-146 (TM3) and Arg-32 (TM1) in 
A
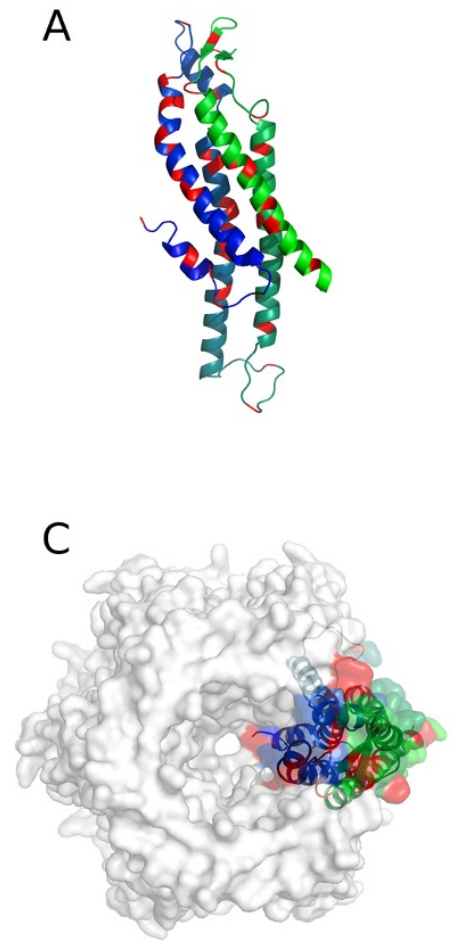

B

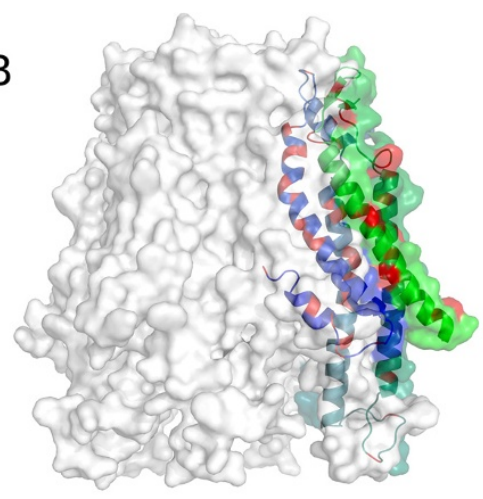

D

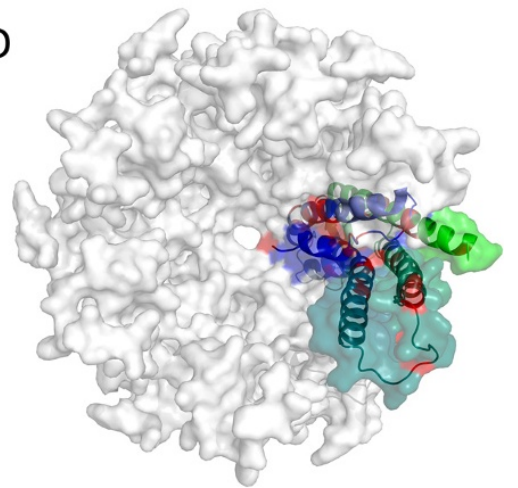

Fig. 1 Localization of loss-of-function mutations for Cx26 GJC. a Cartoon representation of a Cx26 monomer, colored with a blue-green gradient from the $\mathrm{N}$ - to the CT region. Localization of loss-of-function mutations are colored in red. b Lateral (c) Top (d) Bottom view of the same subunit of (a), in the context of the HC assemble. The HC surface is transparent and white. The figure was generated with PyMol and edited with Gimp

Cx32; and between Lys-22 (TM1) and Glu-209 (TM4) in Cx26, might sustain intraprotomer stability [14]. Nevertheless, the crystal structure of Cx26 showed that the main interactions between protomers occur at the extracellular side of the TM2 and TM4. Moreover, an aromatic cluster formed by the extracellular loops and TM3 also participates in inter-protomer interaction [15]. However, the oligomerization compatibility between Cxs has been associated to specific residues in the NT region $[13,16]$.

Cxs oligomerize to form a pore whose narrowest part is observed at the ECLs, near the docking zone $[15,17]$. As mentioned above, the differences in the amino acid sequences among Cxs may influence the channel properties. It has been proposed that the membranespanning regions of $\mathrm{Cxs}$ are not only important for intra- and inter- protomer interactions, but they also might determine functional properties such as gating, permeability and the pore's structure. Concerning the pore composition, there is some controversy about which TMs domains are involved. Some works pointed out the TM3 in Cx32 channels [11, 18] and TM1 in Cx46 channels $[19,20]$ as principal pore helix components. In support of the role of TM1 as a pore lining segment, it has been proposed that the voltage dependent loop-gating mechanism in the $\mathrm{Cx} 32{ }^{*} \mathrm{Cx} 43$ EL1 chimera (in which the ECL1 of Cx43 replaced the ECL1 of Cx32), involves a rotation of TM1 together with an inward tilt of the six protomers [21]. The $3.5 \AA$ A resolution of the Cx26 crystal structure revealed that TM1 is the main constituent of the pore [15] (Fig. 1). The structure also showed that the TM2 lines the pore but in a minor extent, whereas TM3 and TM4 face the hydrophobic membrane environment. The TM1 is tilted, which narrow the pore diameter to $14 \AA$ from the cytoplasmic to the extracellular side of the membrane [15]. More recently, performing molecular dynamic refinements of the crystal structure of Cx26, Kwon and coworkers (2011) [22], shown that the narrow part of the pore could be even smaller.

As it was proposed previously for Cx32 [23] and then confirmed by Maeda and co-workers for Cx26 [15], the $\mathrm{Cx}-\mathrm{NT}$ domain is located inside the pore, facing the TM1s and forming a funnel like structure that might restricts the pore diameter during gating process [15]. The intra-pore stabilization of the NT is achieved by 
hydrophobic interactions between residues Trp-3 (NT) and Met-34 (TM1) from neighboring protomers [15]. This interaction was previously proposed by Oshima and co-workers (2007), which found a prominent pore electron-density in the middle of the pore generated by the deafness mutant Cx26M34A. A reduction of this pore electron-density was observed when residues 2-7 (Cx26M34A-del2-7) were deleted [24], confirming the NT as major contributor to the pore occlusion.

Experiments using a chimeric $\mathrm{HC}$ of $\mathrm{Cx} 32 \% \mathrm{Cx} 43 \mathrm{ECL} 1$, have provided more insight about the gating-mechanism of Cx-based channels [21]. In this chimera, the Cys substitution of the Ala residues in positions 40 and 43, located at the TM1/E1 border, form disulphide bonds with adjacent protomers when the cells are bathed in solutions expected to keep HCs closed $\left(5 \mathrm{mM} \mathrm{Ca}^{2+}\right.$ or $10 \mu \mathrm{M}$ $\left.\mathrm{Cd}^{2+}\right)$. These results strongly suggest a role for these residues in the "loop-gating" mechanism and extracellular $\mathrm{Ca}^{2+}$ regulation of $\mathrm{HCs}[21,25]$.

\section{GJCs and HCs gating regulation}

How gating and permeability are regulated in Cxs- based channels is a matter of intense debate. To date, three types of gating mechanism have been proposed: 1) The NT as a voltage-sensor domain: that plugs the channel vestibule and contribute to the fast or $\mathrm{V}_{(\mathrm{j})}$-gating $\left.[15,26], 2\right)$ The Loop gating: in which extracellular divalent cations (p.g., $\mathrm{Ca}^{2+}$ ) binds to the extracellular loops and blocks HCs by stabilizing the closed loop gate conformation [25, 27], and 3) The ball-and-chain model: which proposes that the CT as part of a ball-and-chain mechanism to regulate the gating of HCs. The last mechanism involves CT conformational rearrangements elicited by voltage or chemical ( $\mathrm{pH}$, redox, phosphorylation) stimuli, which promote a link between this segment and the ICL, and regulates the fast $\mathrm{V}_{(\mathrm{j})}$-gating mechanism [28-33]. This interaction requires the formation of alpha helical structures on the ICL peptide, in which the CT binds upon intracellular acidification [30].

Considering the relevance of the aforementioned mechanisms for channel function, it is critical to understand how Cxs mutations linked to diseases impair these processes. In the next sections, we describe genetic diseases associated to four Cxs that we used as models for the purpose of this review. For space reason, we did not include information about other important Cxs with mutations associated to disease, like Cx46 mutations linked to congenital cataracts $[6,34]$ or increased risk to developing diseases, like in polymorphisms in Cx37 genes associated to cardiovascular diseases [35].

\section{Disease associated to Cx26 mutations}

Genetic sensorineural hearing loss is associated mainly to mutations in Cx26 [36] (Table 1). Two clinical phenotypes derive from Cx26 mutations: 1) nonsyndromic deafness, in which patients evince moderated to severe deafness with absence of other pathological manifestation; and 2) syndromic deafness, in which profound sensorineural hearing loss is accompanied by a range of severe tissue defects such as the observed in palmoplantar keratoderma [37, 38], keratitis ichthyosis deafness syndrome (KID) [39-42], Vohwinkel syndrome [43], histrix-like ichthyosis with deafness syndrome and Bart-Pumphrey syndrome [44, 45].

Among the attempts to identify the pathogenic mechanism of KID syndrome, two transgenic animal models have been developed. They express the Cx26S17F and Cx26G45E mutations in the skin and/or cochlea $[46,47]$ and exhibit similar phenotypes than humans. Experimental results strongly support that the possible mechanisms in the skin might include the impairment of the epidermal calcium homeostasis and the disruption of the water barrier due to abnormal lipid composition of the stratum corneum [48]. For hearing loss, several hypotheses have been proposed. They include loss of $\mathrm{Ca}^{2+}$ homeostasis and ATP release $[49,50]$, impaired permeability to Ins $(1,3,4)$ P3 [51], loss of the endocochlear potential by deficient $\mathrm{K}^{+}$recycling between the epithelial GJ network and the stria vascularis [52], and developmental malformation or cochlear degeneration induced by massive cell death [53, 54]. For comprehensive reviews see $[4,55]$.

\section{Disease associated to $\mathrm{C} \times 32$ mutations}

Cx32 is expressed in several cell types, including the myelin-forming cells in both the peripheral and central nervous systems (CNS); the Schwann cells and oligodendrocytes, respectively. Mutations in this protein are associated to the most common X-linked inheritance form of the Charcot-Marie-Tooth disease (CMT), a pathology referred as CMT1X that accounts for the $10 \%$ of all the CMT cases [56-58]. Due to its X-linkage, males display moderate to severe symptoms $[59,60]$, while milder phenotypes are observed in heterozygous females [61, 62].

In the peripheral nervous system, mutations in Cx32 induce progressive muscular atrophy and variable sensory loss, symptoms associated to slow axonal conduction and distal axonal loss [63]. However, prolonged central conductions times of sensory inputs also arise as consequence of Cx32 missense mutations [64-66].

Cx32 localizes in the axonal paranodes and SchmidtLantermann incisures [67-69] of the peripheral nerves. Hence, GJC made by this protein do not connect adjacent cells but contiguous loops of non-compact myelin. These channels likely act as a preferential diffusion pathway, significantly decreasing the distance between the nucleus and the adaxonal membrane of the myelin sheaths $[67,70]$. 
Table 1 Effect of mutations in Cx26 (GJB2) on the functional state of HCs and GJCs evaluated in a heterologous expression system, the domain that is affected and its phenotype

\begin{tabular}{|c|c|c|c|c|}
\hline Domain & Mutation & GJCs Function & $\begin{array}{l}\text { HCs } \\
\text { Function }\end{array}$ & Deafness Phenotype \\
\hline \multirow[t]{6}{*}{ NT } & M1V, T8M, G12V $[13,123,132-136]$ & $(-)$ & n.d. & NS, Profound, Moderate \\
\hline & G11E $[130,136,137]$ & n.d. & $(+)$ & S, Profound. KID \\
\hline & 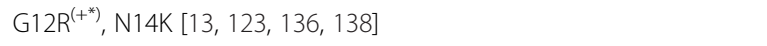 & $(-)$ & $(+)$ & S, Mild, Severe. KID/EKV \\
\hline & N14D [139] & n.d. & $(-)$ & NS, Moderate \\
\hline & $\mathrm{N} 14 \mathrm{Y}^{(+*)}[13,39,136]$ & $(-)$ & $(+)$ & S, Profound. KID \\
\hline & 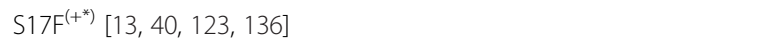 & $(-)$ & $(-)$ & S, SNHL. KID \\
\hline \multirow[t]{5}{*}{ TM1 } & V27I [140] & Normal & Normal & NS, HL and Normal \\
\hline & I33T [141] & $(-)$ & n.d. & NS, Severe to Profound \\
\hline & M34T $[36,115,142-146]$ & $(-)$ & $(-)$ & $\begin{array}{l}\text { NS, Mild to Moderate; S, Profound. } \\
\text { PPK }\end{array}$ \\
\hline & V37I, A40G [113, 143, 147-149] & $(-)$ & $(-)$ & NS, Mild-Moderate, Severe \\
\hline & A40V $[124,136,150,151]$ & Normal & $(+)$ & S, Profound. KID \\
\hline \multirow[t]{8}{*}{ ECL1 } & DelE42, D66H [152-159] & $(-)$ & n.d. & $\begin{array}{l}\text { S, Profound, Moderate to Profound. } \\
\text { PPK }\end{array}$ \\
\hline & W44C, W44S, D46E, T55N [142, 143, 152, 153, 159-163] & $(-)$ & n.d. & $\begin{array}{l}\text { NS, Severe to Profound, } \mathrm{HL} \text {, } \\
\text { Moderate, Severe }\end{array}$ \\
\hline & G45E $[124,130,150,164-166]$ & Normal & $(+)$ & S, Profound. KID \\
\hline & E47K $[164,167]$ & $(-)$ & $(-)$ & NS, Severe to Profound \\
\hline & D50A $[168,169]$ & n.d. & $(+)$ & S, Profound. KID \\
\hline & D50N $[123,137,151,170-172]$ & $(-)$ & $(+)$ & S, Profound. KID \\
\hline & G59V $[144,173]$ & n.d. & $(-)$ & NS, Profound \\
\hline & R75Q, R75W $[37,134,136,141,152-154,174]$ & $(-)$ & $(-)$ & S, Severe to Profound. PPK \\
\hline \multirow[t]{5}{*}{ TM2 } & W77R, F83L, L90V, V95M $[37,135,142,143,147,173,175,176]$ & $(-)$ & n.d. & $\begin{array}{l}\text { NS, Moderate to Profound, } \\
\text { Moderate, Profound }\end{array}$ \\
\hline & I82M [144, 177] & n.d. & $(-)$ & NS, Profound \\
\hline & V84L $[51,147,148,178,179]$ & $\begin{array}{l}\text { Normal/No IP3 } \\
\text { transfer }\end{array}$ & n.d & NS. Profound \\
\hline & T86R, A88S, L90P $[132,143,144,147,160,180]$ & $(-)$ & $(-)$ & $\begin{array}{l}\text { NS, Profound, Moderate to Profound, } \\
\text { Mild to Moderate }\end{array}$ \\
\hline & A88V $[136,168,181]$ & n.d. & $(+)$ & S, Severe to Profound. KID \\
\hline \multirow[t]{2}{*}{$\mathrm{ICL}$} & E114G, R127H $[115,140,144,173,178,182,183]$ & $(-)$ & $(-)$ & NS, Severe to Profound, Profound \\
\hline & DelE120 $[141,143,147]$ & $(-)$ & n.d. & NS, Severe to Profound \\
\hline \multirow[t]{2}{*}{ TM3 } & R143Q, R153I $[133,152,153,183,184]$ & $(-)$ & n.d. & NS, Profound \\
\hline & R143W $[133,144,178,185,186]$ & $(-)$ & $(-)$ & NS, Profound \\
\hline \multirow[t]{3}{*}{ ECL2 } & $\begin{array}{l}\text { F161S, P173R, D179N, R165W, W172R, R184P, R184Q [132, 141, 143, } \\
147,152,153,187-190]\end{array}$ & $(-)$ & n.d. & $\begin{array}{l}\mathrm{NS}, \mathrm{HL} \text {, Severe to Profound, } \\
\text { Profound }\end{array}$ \\
\hline & M163L [191] & n.d & $(+)$ & NS, Moderate to Profound \\
\hline & S183F $[136,192]$ & $(-)$ & n.d. & S, High Frequency HL. PPK \\
\hline \multirow[t]{3}{*}{ TM4 } & M195T, A197S,206S, L214P [133, 135, 190, 193, 194] & $(-)$ & n.d. & NS, HL, Moderate, Profound \\
\hline & C202F $[153,193,195]$ & n.d. & $(-)$ & NS, Mild to Moderate \\
\hline & I203T, L205V [179, 193, 196] & $(-)$ & $(-)$ & NS, HL, Profound \\
\hline
\end{tabular}

NS Non-syndromic, S Syndromic, KID Keratitis-Ichthyosis-Deafness, EKV Erythrokeratodermia variabilis, PPK Palmoplantar Keratoderma-deafness, HL Hearing loss. $\left(+^{*}\right)=$ Generate gain of HC function when they are coexpressed with wild type Cx26 or Cx43 [13]

$(-)=$ Loss of function. $(+)=$ Gain of function. n.d. $=$ not determined 
The peripheral pathological mechanisms associated to Cx32 mutations possibly involve the loss of function of the GJC (Table 2), either by intracellular retention or the production of channels with aberrant properties [70-72]. This lack of functionality might reduce the transfer of signaling molecules, like cAMP, between the adaxonal portions and the nucleus of the Schwann cell [73].

Furthermore, at least some effects of Cx32 mutations have been associated to a gain of function of the GJC (Table 2). Nevertheless, this is based on indirect electrophysiological studies performed in two patients who do not express Cx32; these patients display visual and auditory evoked responses with normal central conduction times [74, 75]. However, the absence of central functional disruptions in most CMT1X patients and $\mathrm{Cx} 32-\mathrm{KO}$ animals supports the hypothesis of gain of function of GJC in patients where disease also affects CNS [61, 76, 77]. However, further studies about the functional properties of the Cx32 channels are required to support these hypothesis.

\section{Disease associated to $\mathrm{Cx} 43$ mutations}

Oculodentodigital Dysplasia (ODDD) is the most important human disease related to $\mathrm{Cx} 43$ mutations (Table 3). ODDD is a autosomal inherited developmental disorder affecting face, eyes, teeth and limbs (reviewed in $[1,78])$. This pathology was linked to a germ line Cx43 gene (GJA1) mutation [79]. The phenotype varies from syndactyli type III alone, to ODDD without syndactyli [80, 81], camptodactyli [79], cardiac impairments, mild cognitive retardation [82] and skeletal abnormalities, which could be associated to impaired osteoblast differentiation [83].

Currently, over 74 mutations related with ODDD have been reported. However, less than a half of these mutations have been characterized. Missense mutations of

Table 2 Effect of mutations in Cx32 (GJB1) on the functional state of HCs and GJCs evaluated in a heterologous expression system, the domain that is affected and its phenotype

\begin{tabular}{|c|c|c|c|c|}
\hline Domain & Mutation & GJCs Function & HCs Function & CMTX Phenotype \\
\hline NT & W3A, W3S, W3Y, G12S, W13L, V13L, R15W, R22G, R22X [127, 197-203] & $(-)$ & n.d. & $\begin{array}{l}\text { Mild to Severe, Severe, Mild to } \\
\text { Moderate, Not described }\end{array}$ \\
\hline \multirow[t]{2}{*}{ TM1 } & S26L, M34K, A39V, A40V [70, 71, 204, 205] & $(-)$ & n.d. & Mild, Not Described \\
\hline & M34T, V35M, V38M [70, 205, 206] & $(-)$ & n.d. & Mild to Moderate, Severe \\
\hline ECL1 & G45E [207] & n.d. & $(+)$ & Not Described \\
\hline \multirow[t]{2}{*}{ ECL1 } & C53S, C60F, Y65C, R75P [203, 205, 208-210] & $(-)$ & n.d. & Not Described \\
\hline & T55I, R75Q, R75W [72, 204, 205, 209, 210], & $(-)$ & n.d. & Mild \\
\hline \multirow[t]{4}{*}{ TM2 } & S85C $[127,211]$ & n.d. & $(+)$ & Severe, Mild \\
\hline & T86A, T86S, T86N, T87A [70, 212] & $(-)$ & $(-)$ & Not Described, Mild \\
\hline & H94Y, H94Q [127, 206] & $(-)$ & n.d. & Mild to Moderate \\
\hline & M93V, V95M [203, 204, 206] & $(-)$ & n.d. & Not Described, Mild to Moderate \\
\hline \multirow[t]{2}{*}{$\mathrm{ICL}$} & E102G, Null111-116 [71, 198, 202, 213] & $(-)$ & n.d. & Mild, Mild to Moderate \\
\hline & R107W, R129H [203, 214] & $(-)$ & n.d. & Mild to Moderate, Not described \\
\hline TM3 & V139M, V140E, R142W [127, 197, 209, 215-219] & $(-)$ & n.d. & $\begin{array}{l}\text { Mild to Moderate, Mild to Severe, } \\
\text { Moderate to Severe }\end{array}$ \\
\hline \multirow[t]{3}{*}{ ECL2 } & L143P, L156R $[203,218]$ & $(-)$ & n.d. & Mild to Moderate \\
\hline & R164Q, V181A, E186K $[197,204,206,213,214,216,219]$ & $(-)$ & n.d. & Moderate to Severe \\
\hline & R164W, P172R, S182T, R183H [72, 198, 203, 204, 206, 208] & $(-)$ & n.d. & Mild to Moderate, Not Described \\
\hline \multirow[t]{3}{*}{ TM4 } & G199R, R203C, N205I [203, 205, 206, 214] & $(-)$ & n.d. & Moderate to Severe, Not Described \\
\hline & E208K, R208K $[197,202,203,216,220,221]$ & $(-)$ & $(-)$ & Moderate to Severe \\
\hline & Y211X [203, 222] & $(-)$ & n.d. & Severe \\
\hline \multirow[t]{5}{*}{$C T$} & R215W [206, 209, 221] & $(-)$ & $(-)$ & Mild to Moderate \\
\hline & C217X $[198,220]$ & n.d. & $(-)$ & Severe \\
\hline & R220X [71, 197, 198, 206, 220] & $(-)$ & n.d. & Moderate to Severe \\
\hline & F235C [126] & n.d. & $(+)$ & Severe \\
\hline & R265X [198] & $(-)$ & $(-)$ & Severe \\
\hline
\end{tabular}

$(-)=$ Loss of function. $(+)=$ Gain of function. n.d. $=$ not determined 
Table 3 Effect of mutations in Cx43 (GJA1) on the functional state of HCs and GJCs evaluated in a heterologous expression system, the domain that is affected and its phenotype

\begin{tabular}{lllll}
\hline Domain & Mutant & GJCs Function & HCs Function & Phenotype \\
\hline NT & G2V, D3N, W4A, L7V, L11P, S18P [79, 92, 223-225] & $(-)$ & n.d. & ODDD \\
& G12R, Y17S [79, 90, 92, 223, 226-228] & $(-)$ & $(-)$ & ODDD \\
TM1 & I31M [91, 229] & $(-)$ & $(+)$ & ODDD \\
& R33X [81, 230] & $(-)$ & n.d. & Small deep-set eyes, syndactyli, dental abnormalities \\
ECL1 & A40V, L90V, F52dup [79, 226, 227, 229, 231] & $(-)$ & $(-)$ & ODDD \\
& E42K [232, 233] & $(-)$ & n.d. & Sudden infant death, lethal ventricular arrhythmias \\
& Q49K [79, 227, 231, 234] & $(-)$ & n.d. & ODDD \\
& S69P [235] & $(-)$ & n.d. & Nonsyndromic Hearing Loss \\
& R76H [230, 236] & $(-)$ & n.d. & Hallermann-Streiff syndrome: small stature, hypotrichosis, \\
ICL & I130T [79, 89, 226, 227] & $(-)$ & $(-)$ & ODDD \\
& K134E, T154A [89, 226, 236-239] & $(-)$ & n.d. & ODDD \\
& G138R, G143S [79, 89-92] & $(-)$ & $(+)$ & ODDD \\
& H194P [80, 91] & $(-)$ & Normal & ODDD \\
ECL2 & R202H, V216L [79, 92, 226, 228, 229, 231] & $(-)$ & n.d. & ODDD \\
TM4 & Fs230, Fs260 [92, 240] & $(-)$ & n.d. & ODDD \\
& S272P [232] & Normal & n.d. & Sudden infant death \\
CT & T326I [235] & $(-)$ & n.d. & Nonsyndromic Hearing Loss \\
& S364P [98, 241] & $(-)$ & n.d. & Viscero-atrial heterotaxia/heart malformations \\
\hline
\end{tabular}

$(-)=$ Loss of function. $(+)=$ Gain of function. n.d. $=$ not determined

Cx43 associated to ODDD are spread through Cx43 amino acid sequence without a clear pattern (Table 3). However, most mutations concentrate in the first half of the protein, with few localized at the $\mathrm{CT}$ region (Table 3). The CT domain has several residues that may be phosphorylated, and these allow the regulation of processes like communication, trafficking to the plasma membrane and assembly and degradation of the gap junction protein [84]. The CT also interacts with the ZO-1 [85], $\mathrm{v}$-Scr [86] and other proteins, including cytoskeletal proteins [87].

Several mutations associated to ODDD are located in the ICL region of $\mathrm{Cx} 43$ (Table 3), demonstrating the importance of this domain for $\mathrm{Cx} 43$ based channels functionality. ICL is critical for both, the $\mathrm{pH}$-mediated gating and the architecture of the channel pore [88]. For example, the ODDD mutant Cx43G138R, which is located in this domain, results in unfunctional GJCs when expressed in N2A cells [89-92]. In contrast, the mutation increases the $\mathrm{HC}$ activity determined by ATP release measurements [91]. Moreover, a mouse model carrying this mutation (Cx43G138R) exhibits a phenotype that resembled the observed in humans, i.e., craniofacial alterations, bilateral syndactyli, smaller teeth (microdontia), unspecialized enamel hypoplasia, osteopenia and sparse hair [93].
A principal role of Cx43 GJCs in the myocardium is to allow a rapid and coordinated electrical excitation important for the cardiac-action potential propagation. Cx43 is mainly located at the intercalated discs in the ventricular myocardium. The geometrical arrangement of the discs, as well as the total number of GJCs, seems to be determinant for the characteristic anisotropic conduction of the ventricular myocardium. The atrial myocardium expresses high levels of $\mathrm{Cx} 43$ and $\mathrm{Cx} 40$ in addition to small quantities of $\mathrm{Cx} 45$ [94]. In addition, it has been reported that cells forming the conduction system (responsible for rapid electrical signal localization from the sinoatrial node to the ventricles), express $\mathrm{Cx} 43$, Cx45, Cx40, and Cx30 [95, 96]. However, patients with mutation in $\mathrm{Cx} 43$ rarely exhibit cardiac problems (Table 3 ). In addition, congenital heart diseases are not commonly associated to $\mathrm{Cx} 43$ mutations [97]. Until now, only a few cases of Cx43 mutations linked to heart diseases have been reported. For example Ser364Pro, which results in viscera atrial heterotaxia [98] restrict GJCs communication in transfected cells. A subsequent work of Thibodeau et al. [99] showed a frameshift mutation in a patient with atrial fibrillation. This modification involves a single nucleotide deletion (c.932delC) with 36 aberrant amino acids with a consecutive stop codon. Interestingly, the mutation was absent in peripheral blood lymphocytes and the 
immunohistological analysis from left atrial tissue showed areas with normal GJCs localization but at the same time, areas with predominant intracellular retention of $\mathrm{Cx}$.

\section{Disease associated to $\mathrm{Cx} 50$ mutations}

Fibers and epithelial cells in the eye lens are connected through Cx50 GJCs [100-102]. This communication is required to maintain the ionic conditions necessary to avoid the formation of cataract [103], a pathology resulting in the opacity of the lens, restricting the amount of light reaching the retina. The Cx50 mutations (Table 4) have been identified in members of families with inherited cataracts. The phenotype may vary across patients, in which missense locations and frame shifts have been commonly identified (reviewed in [6]).

All Cx50 mutations produce loss of function GJCs, except G46V that produce gain of function GJCs [104]. These mutations could generate both, mislocalization and impaired function of GJCs and HCs (e.g., gating or charge selectivity) [105-107]. At cellular level, it is possible that Cx50 mutations affect the intercellular communication mediated by heteromeric Cx46-Cx50 GJCs. This idea is based on results demonstrating that these Cxs co-localize at GJCs plaques [108-110]. The defective GJCs activity could alter the solute transport between cells and disrupt the $\mathrm{Ca}^{2+}$ homeostasis $[111,112]$. The abnormal ion transport, especially $\mathrm{Na}^{+}$ions, causes lens swelling and ameliorates the fluid circulation inside the structure. These abnormal processes might affect the nutrient transport and the clearance of noxious metabolites, triggering the cataract formation [112].

\section{Location of mutations associated to diseases and their} functional consequences on GJC and HCs

Taking advantage of the natural occurring mutations in Cxs and previous studies focuses in the effect of diseaseassociated mutations on the functional state of GJCs and HCs, we looked for similarities and differences between Cxs regarding the positions of mutations associated to the respective diseases and its functional consequences on GJCs and HCs.

Tables summarize experimental results on GJCs and HCs obtained for different Cxs and disease conditions. They show that independent of the disease and $\mathrm{Cx}$, all mutations produce loss of function of the GJCs, which can be partial or total. The decreased GJCs activity can be consequence of reduced amount of channels in the appositional membranes or changes in the functional properties of single channels.

It has been well established that a loss of function of the GJCs elicited by Cx mutations is sufficient to develop pathology. However, it is not clear if the extent of the loss of function is related to the severity of the disease. An institutive reasoning is that there is a good positive correlation between the severity of the Cx-linked disease and the loss of function of the corresponding GJCs. Unfortunately, the experimental data do not support this statement. On one side, positive correlation can be found when the analysis is restricted to some missense non-syndromic Cx26 mutations (V37I and A40G). While these genetic modifications induce GJCs with loss of function (A40G) and active channels with reduced permeability (V37I) [113], they produce a severe deafness phenotype and

Table 4 Effect of mutations in Cx50 (GJA8) on the functional state of HCs and GJCs evaluated in a heterologous expression system, the domain that is affected and its phenotype

\begin{tabular}{|c|c|c|c|c|}
\hline Domain & Mutation & GJCs Function & HCs Function & Cataract Phenotype \\
\hline NT & R23T [242] & $(-)$ & n.d. & Bilateral nuclear \\
\hline \multirow[t]{3}{*}{ TM1/ECL1 } & V44A [243] & n.d & $(-)$ & Suture-sparing nuclear \\
\hline & V44E [110] & $(-)$ & n.d. & Whole lens \\
\hline & W45S $[106,244]$ & $(-)$ & $(-)$ & Jellyfish-like appearance, Micro cornea \\
\hline \multirow[t]{4}{*}{ ECL1 } & G46V $[104,106]$ & $(+)$ & $(+)$ & Total \\
\hline & D47N $[110,117]$ & $(-)$ & n.d. & Nuclear Pulverulent \\
\hline & E48K $[116,245]$ & $(-)$ & Normal & Zonular Nuclear Pulverulent \\
\hline & S50P $[114,118]$ & $(-)$ & $(-)$ & $\begin{array}{l}\text { Altered fiber cell formation, dense cataract } \\
\text { and posterior capsule rupture }\end{array}$ \\
\hline \multirow[t]{3}{*}{ TM2 } & V79L [110] & $(-)$ & n.d. & "Full moon" with Y-suture Opacities \\
\hline & P88S $[34,246]$ & $(-)$ & n.d. & Zonular Pulverulent \\
\hline & P88Q [247] & $(-)$ & n.d. & Lamellar Pulverulent \\
\hline \multirow[t]{2}{*}{$C T$} & S276F $[248,249]$ & $(-)$ & $(-)$ & Nuclear Pulverulent \\
\hline & Cx50fs [250] & $(-)$ & n.d. & Triangular \\
\hline
\end{tabular}

$(-)=$ Loss of function. $(+)=$ Gain of function. n.d. $=$ not determined 
a milder condition, respectively [4]. However, a clear correlation cannot be established when other mutations are analyzed, such as some $\mathrm{Cx} 32$ mutations associated to a mild to moderate (Null111-116) and moderate to severe (R220X) CMTX1 phenotypes. As expected, the permeability of these channels to different dye tracers decreases as the size of the probe increases [114]. However, unlike the channels containing the Null111-116 mutation, permeability of the R220X-Cx32 GJCs to small probes (neurobiotin) is not significantly different from that observed in wild type channels [115]. In the same region (TM1-ECL1) other mutations cause nonfunctional GJCs and HCs (eg. E48K, D47N, S50P) [110, 116-118]. In contrast, Cx50 W45S acts as a dominant negative when co-expressed with Cx50, reducing GJCs coupling between fibers cells [106]. The above evidences suggest that the disease mechanisms might be produced by subtle changes in GJCs permeability, which are impossible to detect by the common electrophysiological and dye coupling methodologies.

In order to know the location of mutations in the channel structure, we produced several molecular models of the different Cxs by homology modeling, taking the crystal structure of Cx26 GJC published by Maeda et al., (2009) as template [15]. Due to the lack of experimental structure for human Cx32, Cx43 and Cx50, we generated comparative structural models, using Modeller [119], based on the structure of human Cx26 as a template (pdb: 2ZW3) (Figs. 2 and 3). Missing residues of human Cx26 structure were inserted with Modeller. The backbone of the experimental Cx26 structure was fully conserved. Ten models were generated in each case and those with the lowest discrete optimized protein energy (DOPE) score were selected as the final models. Figure 1 shows the model of a Cx26 monomer in the context of the connexon as well the location of residues mutated in genetic deafness that produce loss of function GJCs. Clearly, although loss of function mutations can be located everywhere in the protomer, they are concentrated from the NT to the TM2 domains (Fig. 1), regions that line the pore and are critical for voltage gating, as we mentioned earlier [120]. Moreover, other mutations in the transmembrane regions seem to be located in protein-protein and protein-lipid interfaces (Fig. 1b, c). Those locations could be important for intra- or inter-protomer interactions [121], which might stabilize the channel or contribute GJCs channel assembly. For $\mathrm{Cx} 32$, the pattern for location of mutations that produced loss of function GJCs is very similar to that observed for Cx26 (Fig. 2b), suggesting strong similarities in the structural features between these two Cxs. For Cxs 43 and 50, mutations that produce loss of GJCs function are more restricted. The fact that they localize mostly from NT to ECL1 (Fig. 2c, d) confirms the importance of this region for the channel function in the whole Cx family. However, the ICL Cx43 also presents important amount of mutations producing loss of function GJCs (Table 3).

\section{Mutations affecting HCs function}

The HCs play important role in physiological and pathological conditions since they provide a route for paracrine/autocrine signaling between the cell and the extracellular environment [2, 122]. Hence, a plausible underlying mechanism for connexinopathies is the possibility that some disease condition arise upon HCs dysfunction. For example, aberrant gain of function $\mathrm{HCs}$ is associated to syndromic Cx26 mutations that lead to keratitis ichthyosis deafness syndrome (KID) $[13,123,124]$. For the other Cxs (Cx32, Cx43 and Cx50), very few cases have been reported making it difficult to establish a common mechanism of disease (Tables 1, 2, 3 and 4). Exceptions are some mutations in $\mathrm{Cx} 32$ (S85C and $\mathrm{F} 235 \mathrm{C}$ ), which induce aberrant gain of $\mathrm{HC}$ activity in CMTX1 [125, 126], which behaves similar to the KID-linked Cx26 mutations, i.e., causing a gain of function of the HCs [125] and a loss of function of the GJCs [127]. Although the S85C mutant induces abnormal $\mathrm{HCs}$ opening [128], this mutation has not been associated to any particular severe phenotype of CMTX1 [129].

Most of the mutations eliciting gain of $\mathrm{HCs}$ function are clustered exclusively in the pore lining residues of the NT, TM1 and the ECL1. They also localize in TM2 to a lesser extent (Fig. 3). In the case of Cx26, several mutations related to severe clinical phenotypes of KID are located at the transition zone between TM1 and the ECL1, a domain involved in both voltage gating and the control of HCs by extracellular $\mathrm{Ca}^{2+}[25]$. Moreover, a cluster of syndromic mutations is found in the NT domain of the protein, which is involved in the fast gating of $\mathrm{HCs}[24,130]$. Nevertheless, a role of other regions on the regulation of $\mathrm{HCs}$ should be further considered. For example, the Cx32 mutation $\mathrm{F} 235 \mathrm{C}$, localized in the CT of the protein also induces HCs with gain of function [126].

The gain of HCs function has been also observed in Cx43 related connexinopathies, since mutations I31M (TM1), G138R (ICL) and G143S (ICL), all promotes gain of function (Table 3). As mentioned above, ICL is involved in regulation the fast $\mathrm{V}(\mathrm{j})$-gating, which depend on the interaction with CT [28-32]. Moreover, Dobrowolski and co-workers (2008) [93] found an increased ATP-release in cultured cardiomyocytes from cardiac specific G138R-mutant mice. Interestingly, the authors proposed that HCs with gain of function in G138Rmutated cardiomyocytes might be one of the causes of arrhythmias. 

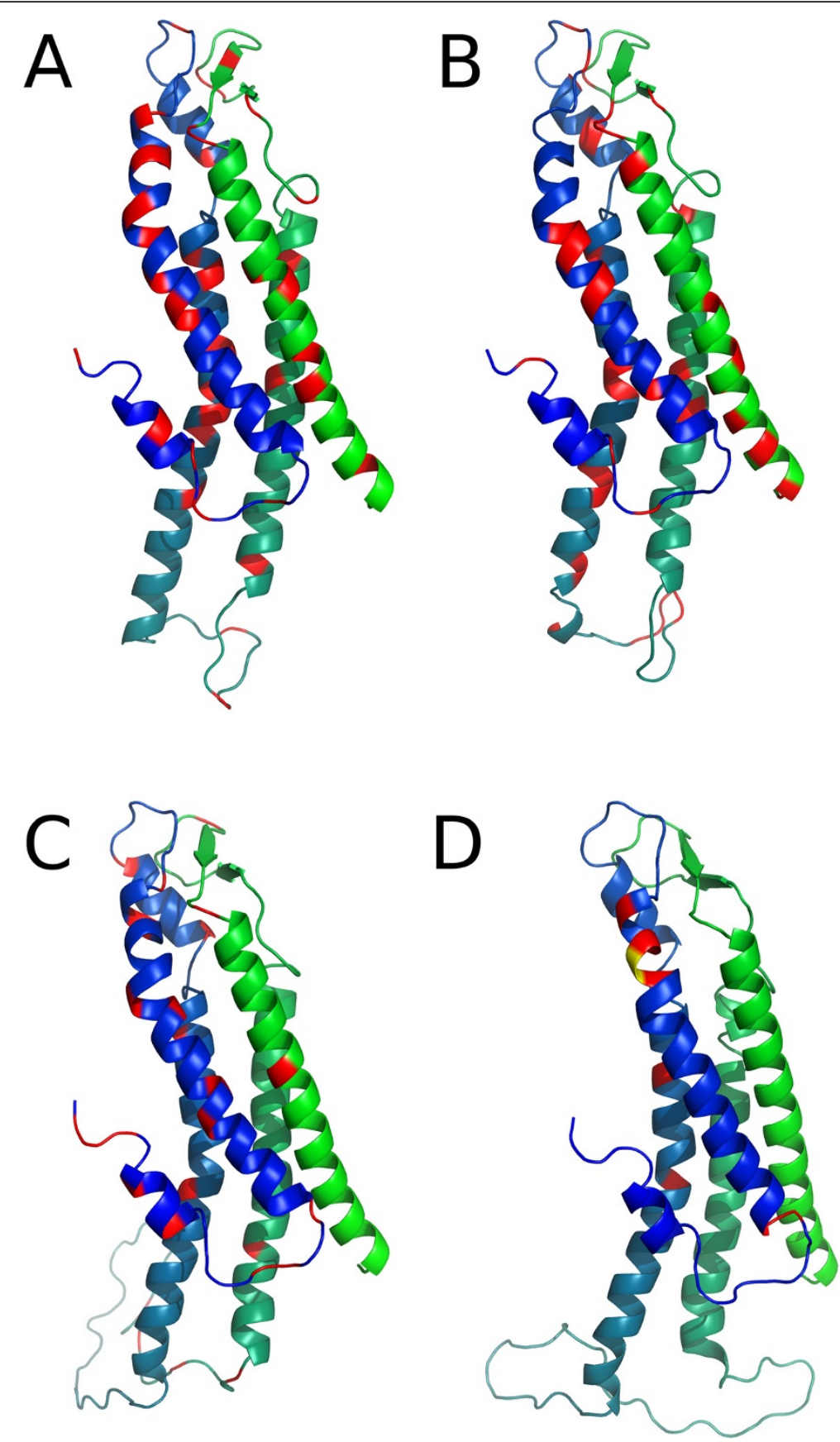

Fig. 2 Mutations affecting function of GJCs. Models of single Cxs chains are represented as cartoons, and colored with a blue-green gradient from the $\mathrm{N}$ - to the CT region, for (a) Cx26 (b) Cx32, (c) Cx43 and (d) Cx50. Positions of loss of function mutations are colored as red and gain of function mutations as yellow. The figure was generated with Pymol and edited with Gimp

As expected, some mutations induce loss of function HCs (Table 1 and Fig. 3). For example, mutations related to non-syndromic sensorineural hearing loss generate non-functional HCs [113]. Indeed, there are some syndromic mutations that exhibit non-functional HCs that only become gain of function when are co-expressed with their wild type partner or under aberrant interaction with Cx43 [13, 131].
Finally, It should be considering that in normal tissues cells could express several Cxs isoforms raising the possibility of interaction among Cxs isoforms. Recent results obtained in Dr. Martinez' lab [13] and Dr. White's group [131] suggest that the interaction between the mutated $\mathrm{Cx}$ and the co-expressed Cxs forming heterotypic/heteromeric channels needs to be taking into account to explain the clinical phenotypes 

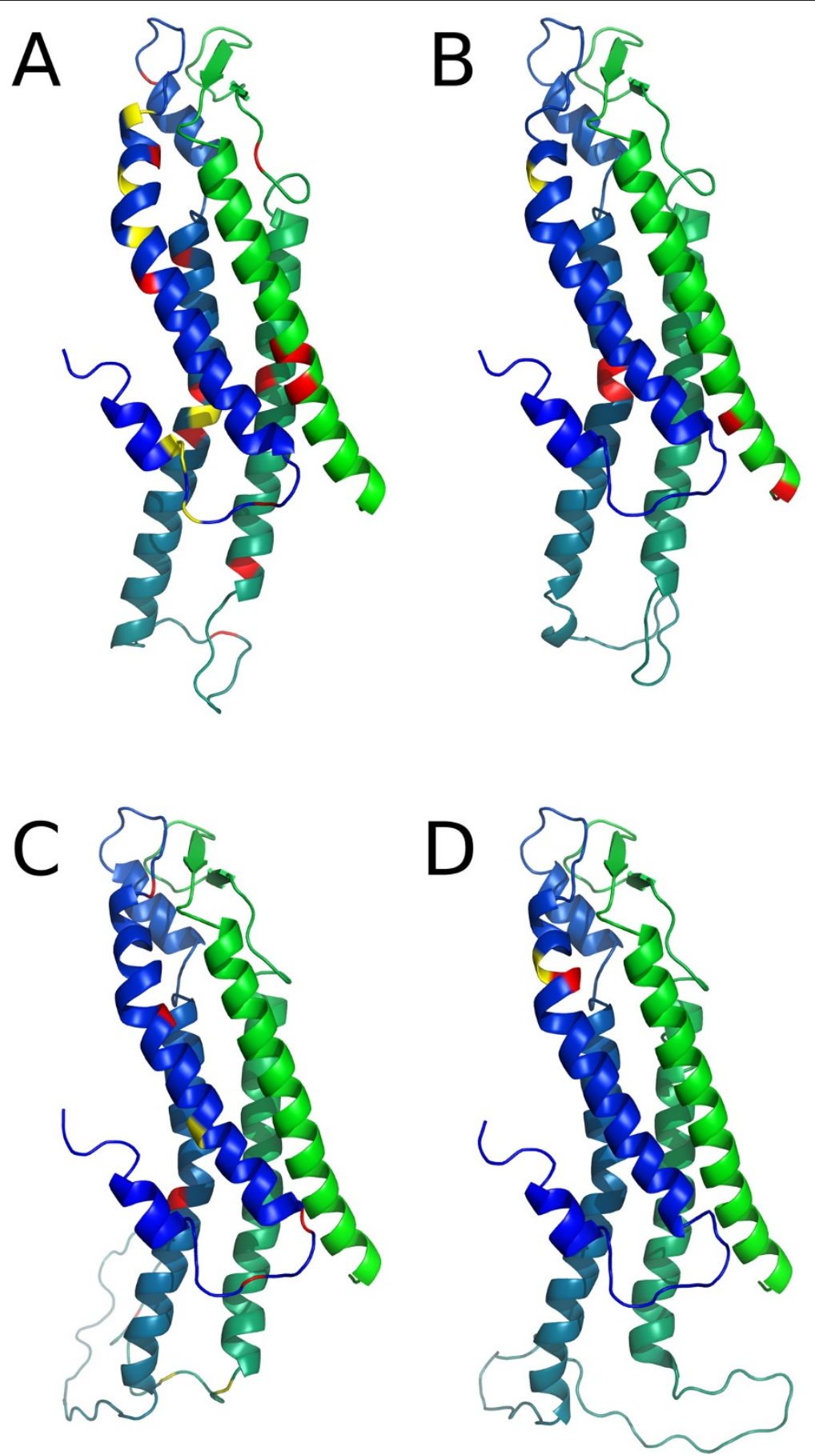

Fig. 3 Mutations affecting function of HCs. Models of single Cxs chains are represented as cartoons, and colored with a blue-green gradient from the $\mathrm{N}$ - to the $\mathrm{CT}$ region, for (a) $\mathrm{C} \times 26$ (b) $\mathrm{C} \times 32$, (c) $\mathrm{C} \times 43$ and (d) Cx50. Positions of loss of function mutations are colored as red and gain of function mutations as yellow. The figure was generated with PyMol and edited with Gimp

of connexinopathies. Thus, interaction of mutants with wild type Cxs might ameliorate or worsen the clinical phenotypes. This possibility might augment when mutations affect critical segment involved in oligomerization compatibility, giving rise to aberrant heteromeric $\mathrm{HCs}$, which makes pathological condition and effective treatment complex. In this scenario, further studies attempting to explore the pathological mechanism of connexinopathies should consider to study $\mathrm{Cxs}$ in heteromeric rather than homomeric states, which more closely resembles native cellular conditions. 


\section{Conclusions}

Most mutations causing connexinopathies generates total or partial loss of GJCs function. However, it is unclear if the severity of disease correlates with the level of GJCs loss of function. Mutations associated with loss of function GJCs are distributed along the entire protein sequence with no clear pattern of clustering at any segment, which suggest that GJC functionality is very sensitive to minor changes in Cxs protein, and that subtle changes in GJC functionality are sufficient to cause diseases. Less in known about the effect of mutations associated to connexinopathies on the functional state of HCs. The clearest correlation between gain of function HCs and disease has been found in most types of syndromic deafness associated to Cx26, in particular in KID syndrome. For others Cxs, few mutations are associated to gain of HCs function, however, we can not discard that this condition may be underestimated because most studies in the past have been more focused in GJCs than HCs. Therefore, it is yet difficult to make a general statement that represent all Cxs associated to connexinopathies. Nevertheless, it is clear that all mutations eliciting gain of $\mathrm{HCs}$ function are clustered in pore-associated domains like the NT and the TM1/ECL1, which are critical regions for gating and regulation.

\section{Competing interests}

The authors declare that they have no competing interests.

\section{Authors' contributions}

ADM, conceived the original idea. IEG, PP, and ADM co-wrote and co-edited the final version of the manuscript. AP, made the molecular models of Cxs subunits; OJ, PM, DRG, CFM, JGC, CSR, BIP, MAR and CG, co-designed and cowrote the tables and contributed to the discussion. All authors read and approved the final manuscript.

\section{Acknowledgements \\ This work was supported by Anillo \#ACT 1104 (to ADM, CG and MAR), Fondecyt \#1130855 (to ADM) and \#1120214 (to MAR), and Fondecyt Postdoctoral \#3150634 (to IEG) and \#3150442 (to PP). The Centro Interdisciplinario de Neurociencias de Valparaíso is a Chilean Millennium Institute (P09-022-F).}

\section{Declarations}

Publication charge for this article was funded by grant Fondecyt \#1130855 (to ADM).

This article has been published as part of BMC Cell Biology Volume 17 Supplement 1, 2016: Proceedings of the International Gap Junction Conference 2015. The full contents of the supplement are available online at http://bmccellbiol.biomedcentral.com/articles/supplements/volume-17supplement-1.

\section{Author details}

${ }^{1}$ Centro Interdisciplinario de Neurociencia de Valparaíso, Instituto de Neurociencia, Facultad de Ciencias, Universidad de Valparaíso, Valparaíso, Chile. ${ }^{2}$ Centro de Fisiología Celular e Integrativa, Facultad de Medicina, Clínica Alemana Universidad del Desarrollo, Santiago, Chile.

Published: 24 May 2016

\section{References}

1. Laird DW. Syndromic and non-syndromic disease-linked Cx43 mutations. FEBS Lett. 2014;588(8):1339-48.
2. Sáez JC, Berthoud VM, Branes MC, Martínez AD, Beyer EC. Plasma membrane channels formed by connexins: their regulation and functions. Physiol Rev. 2003;83(4):1359-400.

3. Harris AL. Emerging issues of connexin channels: biophysics fills the gap. Q Rev Biophys. 2001;34(3):325-472.

4. Martínez AD, Acuña R, Figueroa V, Maripillán J, Nicholson B. Gap-junction channels dysfunction in deafness and hearing loss. Antioxid Redox Signal. 2009;11(2):309-22.

5. Delmar M, Makita N. Cardiac connexins, mutations and arrhythmias. Curr Opin Cardiol. 2012;27(3):236-41.

6. Beyer EC, Ebihara L, Berthoud VM. Connexin mutants and cataracts. Front Pharmacol. 2013:4:43.

7. Laird DW, Castillo M, Kasprzak L. Gap junction turnover, intracellular trafficking, and phosphorylation of connexin43 in brefeldin A-treated rat mammary tumor cells. J Cell Biol. 1995;131(5):1193-203.

8. Lampe PD, Lau AF. Regulation of gap junctions by phosphorylation of connexins. Arch Biochem Biophys. 2000;384(2):205-15.

9. Ahmad S, Martin PE, Evans WH. Assembly of gap junction channels: mechanism, effects of calmodulin antagonists and identification of connexin oligomerization determinants. Eur J Biochem. 2001;268(16): 4544-52.

10. Maza J, Das Sarma J, Koval M. Defining a minimal motif required to prevent connexin oligomerization in the endoplasmic reticulum. J Biol Chem. 2005; 280(22):21115-21.

11. Fleishman SJ, Unger VM, Yeager M, Ben-Tal N. A Calpha model for the transmembrane alpha helices of gap junction intercellular channels. Mol Cell. 2004;15(6):879-88.

12. Martinez AD, Maripillan J, Acuna R, Minogue PJ, Berthoud VM, Beyer EC. Different domains are critical for oligomerization compatibility of different connexins. Biochem J. 2011;436(1):35-43.

13. García IE, Maripillán J, Jara O, Ceriani R, Palacios-Muñoz A, Ramachandran J, Olivero P, Perez-Acle T, González C, Sáez JC et al. Keratitis-Ichthyosis-Deafness Syndrome-Associated Cx26 Mutants Produce Nonfunctional Gap Junctions but Hyperactive Hemichannels When Co-Expressed With Wild Type Cx43. J Invest Dermatol. 2015; 135(5):1338-47.

14. Fleishman SJ, Sabag AD, Ophir E, Avraham KB, Ben-Tal N. The structural context of disease-causing mutations in gap junctions. J Biol Chem. 2006; 281(39):28958-63.

15. Maeda S, Nakagawa S, Suga M, Yamashita E, Oshima A, Fujiyoshi Y, Tsukihara T. Structure of the connexin 26 gap junction channel at $3.5 \mathrm{~A}$ resolution. Nature. 2009;458(7238):597-602.

16. Lagree V, Brunschwig K, Lopez P, Gilula NB, Richard G, Falk MM. Specific amino-acid residues in the $\mathrm{N}$-terminus and TM3 implicated in channel function and oligomerization compatibility of connexin43. J Cell Sci. 2003; 116(Pt 15):3189-201.

17. Unger VM, Kumar NM, Gilula NB, Yeager M. Three-dimensional structure of a recombinant gap junction membrane channel. Science. 1999; 283(5405):1176-80.

18. Skerrett IM, Aronowitz J, Shin JH, Cymes G, Kasperek E, Cao FL, Nicholson BJ. Identification of amino acid residues lining the pore of a gap junction channel. J Cell Biol. 2002;159(2):349-60.

19. Zhou XW, Pfahnl A, Werner R, Hudder A, Llanes A, Luebke A, Dahl G. Identification of a pore lining segment in gap junction hemichannels. Biophys J. 1997:72(5):1946-53.

20. Kronengold J, Trexler EB, Bukauskas FF, Bargiello TA, Verselis VK. Singlechannel SCAM identifies pore-lining residues in the first extracellular loop and first transmembrane domains of Cx46 hemichannels. J Gen Physiol. 2003;122(4):389-405.

21. Tang Q, Dowd TL, Verselis VK, Bargiello TA. Conformational changes in a pore-forming region underlie voltage-dependent "loop gating" of an unapposed connexin hemichannel. J Gen Physiol. 2009;133(6):555-70.

22. Kwon T, Harris AL, Rossi A, Bargiello TA. Molecular dynamics simulations of the Cx26 hemichannel: evaluation of structural models with Brownian dynamics. J Gen Physiol. 2011;138(5):475-93.

23. Purnick PE, Benjamin DC, Verselis VK, Bargiello TA, Dowd TL. Structure of the amino terminus of a gap junction protein. Arch Biochem Biophys. 2000; 381(2):181-90.

24. Oshima A, Tani K, Hiroaki Y, Fujiyoshi Y, Sosinsky GE. Three-dimensional structure of a human connexin26 gap junction channel reveals a plug in the vestibule. Proc Natl Acad Sci U S A. 2007;104(24):10034-9. 
25. Verselis VK, Srinivas M. Divalent cations regulate connexin hemichannels by modulating intrinsic voltage-dependent gating. J Gen Physiol. 2008;132(3): 315-27.

26. Oh S, Bargiello TA. Voltage regulation of connexin channel conductance. Yonsei Med J. 2015;56(1):1-15.

27. Gomez-Hernandez JM, de Miguel M, Larrosa B, Gonzalez D, Barrio LC. Molecular basis of calcium regulation in connexin-32 hemichannels. Proc Natl Acad Sci U S A. 2003;100(26):16030-5

28. Solan JL, Lampe PD. Connexin43 phosphorylation: structural changes and biological effects. Biochem J. 2009;419(2):261-72.

29. Spray DC, Burt JM. Structure-activity relations of the cardiac gap junction channel. Am J Phys. 1990;258(2 Pt 1):C195-205.

30. Hirst-Jensen BJ, Sahoo P, Kieken F, Delmar M, Sorgen PL. Characterization of the $\mathrm{pH}$-dependent interaction between the gap junction protein connexin43 carboxyl terminus and cytoplasmic loop domains. J Biol Chem. 2007;282(8):5801-13.

31. Elenes $S$, Martinez AD, Delmar M, Beyer EC, Moreno AP. Heterotypic docking of $\mathrm{C} \times 43$ and $\mathrm{C} \times 45$ connexons blocks fast voltage gating of $\mathrm{C} \times 43$. Biophys J. 2001;81(3):1406-18.

32. Revilla A, Castro C, Barrio LC. Molecular dissection of transjunctional voltage dependence in the connexin-32 and connexin-43 junctions. Biophys J. 1999; 77(3):1374-83.

33. Duffy HS, Sorgen PL, Girvin ME, O'Donnell P, Coombs W, Taffet SM, Delmar M, Spray DC. pH-dependent intramolecular binding and structure involving Cx43 cytoplasmic domains. J Biol Chem. 2002; 277(39):36706-14.

34. Berthoud VM, Minogue PJ, Guo J, Williamson EK, Xu X, Ebihara L, Beyer EC Loss of function and impaired degradation of a cataract-associated mutant connexin50. Eur J Cell Biol. 2003;82(5):209-21.

35. Yamada $Y$, Izawa $H$, Ichihara S, Takatsu F, Ishihara $H$, Hirayama $H$, Sone T, Tanaka M, Yokota M. Prediction of the risk of myocardial infarction from polymorphisms in candidate genes. N Engl J Med. 2002;347(24): 1916-23.

36. Kelsell DP, Dunlop J, Stevens HP, Lench NJ, Liang JN, Parry G, Mueller RF, Leigh IM. Connexin 26 mutations in hereditary non-syndromic sensorineural deafness. Nature. 1997:387(6628):80-3.

37. Richard G, White TW, Smith LE, Bailey RA, Compton JG, Paul DL, Bale SJ. Functional defects of $\mathrm{Cx} 26$ resulting from a heterozygous missense mutation in a family with dominant deaf-mutism and palmoplantar keratoderma. Hum Genet. 1998;103(4):393-9.

38. Heathcote K, Syrris P, Carter ND, Patton MA. A connexin 26 mutation causes a syndrome of sensorineural hearing loss and palmoplantar hyperkeratosis (MIM 148350). J Med Genet. 2000;37(1):50-1.

39. Arita K, Akiyama M, Aizawa T, Umetsu Y, Segawa I, Goto M, Sawamura D, Demura M, Kawano K, Shimizu H. A novel N14Y mutation in Connexin26 in keratitis-ichthyosis-deafness syndrome: analyses of altered gap junctional communication and molecular structure of $\mathrm{N}$ terminus of mutated Connexin26. Am J Pathol. 2006;169(2):416-23.

40. Richard G, Rouan F, Willoughby CE, Brown N, Chung P, Ryynanen M, Jabs EW, Bale SJ, DiGiovanna JJ, Uitto J, et aL. Missense mutations in GJB2 encoding connexin-26 cause the ectodermal dysplasia keratitis-ichthyosisdeafness syndrome. Am J Hum Genet. 2002;70(5):1341-8.

41. Mazereeuw-Hautier J, Bitoun E, Chevrant-Breton J, Man SY, Bodemer C, Prins C, Antille C, Saurat JH, Atherton D, Harper Jl, et al. Keratitisichthyosis-deafness syndrome: disease expression and spectrum of connexin 26 (GJB2) mutations in 14 patients. Br J Dermatol. 2007;156(5):1015-9.

42. van Steensel MA, van Geel M, Nahuys M, Smitt JH, Steijlen PM. A nove connexin 26 mutation in a patient diagnosed with keratitis-ichthyosisdeafness syndrome. J Invest Dermatol. 2002;118(4):724-7.

43. Maestrini E, Korge BP, Ocana-Sierra J, Calzolari E, Cambiaghi S, Scudder PM, Hovnanian A, Monaco AP, Munro CS. A missense mutation in connexin26, $\mathrm{D} 66 \mathrm{H}$, causes mutilating keratoderma with sensorineural deafness (Vohwinkel's syndrome) in three unrelated families. Hum Mol Genet. 1999; 8(7):1237-43.

44. van Geel M, van Steensel MA, Kuster W, Hennies HC, Happle R, Steiilen PM, Konig A. HID and KID syndromes are associated with the same connexin 26 mutation. Br J Dermatol. 2002;146(6):938-42

45. Alexandrino F, Sartorato EL, Marques-de-Faria AP, Steiner CE. G59S mutation in the GJB2 (connexin 26) gene in a patient with Bart-Pumphrey syndrome. Am J Med Genet A. 2005;136(3):282-4.
46. Schütz M, Auth T, Gehrt A, Bosen F, Korber I, Strenzke N, Moser T, Willecke $K$. The connexin26 S17F mouse mutant represents a model for the human hereditary keratitis-ichthyosis-deafness syndrome. Hum Mol Genet. 2011; 20(1):28-39.

47. Mese G, Sellitto C, Li L, Wang HZ, Valiunas V, Richard G, Brink PR, White TW. The Cx26-G45E mutation displays increased hemichannel activity in a mouse model of the lethal form of keratitis-ichthyosis-deafness syndrome. Mol Biol Cell. 2011;22(24):4776-86.

48. Bosen F, Celli A, Crumrine D, Vom Dorp K, Ebel P, Jastrow H, Dormann P, Winterhager E, Mauro T, Willecke K. Altered epidermal lipid processing and calcium distribution in the KID syndrome mouse model Cx26S17F. FEBS Lett. 2015;589(15):1904-10.

49. Zhao HB. Connexin26 is responsible for anionic molecule permeability in the cochlea for intercellular signalling and metabolic communications. Eur J Neurosci. 2005;21(7):1859-68.

50. Mammano F. Ca2+ homeostasis defects and hereditary hearing loss. Biofactors. 2011:37(3):182-8.

51. Beltramello M, Piazza V, Bukauskas FF, Pozzan T, Mammano F. Impaired permeability to Ins $(1,4,5) \mathrm{P3}$ in a mutant connexin underlies recessive hereditary deafness. Nat Cell Biol. 2005;7(1):63-9.

52. Zhao HB, Kikuchi T, Ngezahayo A, White TW. Gap junctions and cochlear homeostasis. J Membr Biol. 2006;209(2-3):177-86.

53. Cohen-Salmon M, Ott T, Michel V, Hardelin JP, Perfettini I, Eybalin M, Wu T, Marcus DC, Wangemann P, Willecke K, et al. Targeted ablation of connexin26 in the inner ear epithelial gap junction network causes hearing impairment and cell death. Curr Biol: CB. 2002;12(13):1106-11.

54. Kammen-Jolly K, Ichiki H, Scholtz AW, Gsenger M, Kreczy A, Schrott-Fischer A. Connexin 26 in human fetal development of the inner ear. Hear Res. 2001;160(1-2):15-21

55. Wingard JC, Zhao HB. Cellular and Deafness Mechanisms Underlying Connexin Mutation-Induced Hearing Loss - A Common Hereditary Deafness. Front Cell Neurosci. 2015;9:202.

56. Kleopa KA, Abrams CK, Scherer SS. How do mutations in GJB1 cause Xlinked Charcot-Marie-Tooth disease? Brain Res. 2012;1487:198-205.

57. Murphy SM, Ovens R, Polke J, Siskind CE, Laura M, Bull K, Ramdharry G, Houlden $H$, Murphy RP, Shy ME, et al. X inactivation in females with Xlinked Charcot-Marie-Tooth disease. Neuromuscul Disord. 2012;22(7):617-21.

58. Saporta MA, Shy ME. Inherited peripheral neuropathies. Neurol Clin. 2013; 31(2):597-619.

59. Saporta AS, Sottile SL, Miller LJ, Feely SM, Siskind CE, Shy ME. Charcot-MarieTooth disease subtypes and genetic testing strategies. Ann Neurol. 2011; 69(1):22-33.

60. Latour P, Gonnaud PM, Ollagnon E, Chan V, Perelman S, Stojkovic T, Stoll C, Vial C, Ziegler F, Vandenberghe A, et al. SIMPLE mutation analysis in dominant demyelinating Charcot-Marie-Tooth disease: three novel mutations. J Peripher Nerv Syst. 2006:11(2):148-55.

61. Scherer SS, Xu YT, Nelles E, Fischbeck K, Willecke K, Bone L. Connexin32-null mice develop demyelinating peripheral neuropathy. Glia. 1998;24(1):8-20.

62. Siskind CE, Shy ME. Genetics of neuropathies. Semin Neurol. 2011;31(5): 494-505

63. Abrams CK, Scherer SS. Gap junctions in inherited human disorders of the central nervous system. Biochim Biophys Acta. 2012;1818(8): 2030-47.

64. Nicholson G, Corbett A. Slowing of central conduction in X-linked CharcotMarie-Tooth neuropathy shown by brain stem auditory evoked responses. J Neurol Neurosurg Psychiatry. 1996;61(1):43-6.

65. Srinivasan J, Leventer RJ, Kornberg AJ, Dahl HH, Ryan MM. Central nervous system signs in X-linked Charcot-Marie-Tooth disease after hyperventilation. Pediatr Neurol. 2008:38(4):293-5.

66. Kassubek J, Bretschneider V, Sperfeld AD. Corticospinal tract MRI hyperintensity in X-linked Charcot-Marie-Tooth Disease. J Clin Neurosci. 2005;12(5):588-9.

67. Scherer SS, Deschenes SM, Xu YT, Grinspan JB, Fischbeck KH, Paul DL. Connexin32 is a myelin-related protein in the PNS and CNS. J Neurosci. 1995:15(12):8281-94

68. Altevogt BM, Kleopa KA, Postma FR, Scherer SS, Paul DL. Connexin29 is uniquely distributed within myelinating glial cells of the central and peripheral nervous systems. J Neurosci. 2002;22(15):6458-70.

69. Balice-Gordon RJ, Bone LJ, Scherer SS. Functional gap junctions in the schwann cell myelin sheath. J Cell Biol. 1998;142(4):1095-104. 
70. Oh S, Ri Y, Bennett MV, Trexler EB, Verselis VK, Bargiello TA. Changes in permeability caused by connexin 32 mutations underlie X-linked CharcotMarie-Tooth disease. Neuron. 1997;19(4):927-38.

71. Bicego M, Morassutto S, Hernandez VH, Morgutti M, Mammano F, D'Andrea $P$, Bruzzone R. Selective defects in channel permeability associated with Cx32 mutations causing X-linked Charcot-Marie-Tooth disease. Neurobiol Dis. 2006;21(3):607-17.

72. Sargiannidou I, Vavlitou N, Aristodemou S, Hadjisavvas A, Kyriacou K, Scherer SS, Kleopa KA. Connexin32 mutations cause loss of function in Schwann cells and oligodendrocytes leading to PNS and CNS myelination defects. J Neurosci. 2009:29(15):4736-49.

73. Ressot C, Bruzzone R. Connexin channels in Schwann cells and the development of the X-linked form of Charcot-Marie-Tooth disease. Brain Res Brain Res Rev. 2000;32(1):192-202.

74. Takashima H, Nakagawa M, Umehara F, Hirata K, Suehara M, Mayumi H, Yoshishige K, Matsuyama W, Saito M, Jonosono M, et al. Gap junction protein beta 1 (GJB1) mutations and central nervous system symptoms in X-linked Charcot-Marie-Tooth disease. Acta Neurol Scand. 2003;107(1):31-7.

75. Hahn AF, Ainsworth PJ, Bolton CF, Bilbao JM, Vallat JM. Pathological findings in the $x$-linked form of Charcot-Marie-Tooth disease: a morphometric and ultrastructural analysis. Acta Neuropathol. 2001;101(2):129-39.

76. Anzini P, Neuberg DH, Schachner M, Nelles E, Willecke K, Zielasek J, Toyka KV, Suter U, Martini R. Structural abnormalities and deficient maintenance of peripheral nerve myelin in mice lacking the gap junction protein connexin 32. J Neurosci. 1997;17(12):4545-51.

77. Sutor B, Schmolke C, Teubner B, Schirmer C, Willecke K. Myelination defects and neuronal hyperexcitability in the neocortex of connexin 32-deficient mice. Cereb Cortex. 2000;10(7):684-97.

78. Molica F, Meens MJ, Morel S, Kwak BR. Mutations in cardiovascular connexin genes. Biol Cell. 2014;106(9):269-93.

79. Paznekas WA, Boyadjiev SA, Shapiro RE, Daniels O, Wollnik B, Keegan CE, Innis JW, Dinulos MB, Christian C, Hannibal MC, et al. Connexin 43 (GJA1) mutations cause the pleiotropic phenotype of oculodentodigital dysplasia. Am J Hum Genet. 2003;72(2):408-18.

80. Vitiello C, D'Adamo P, Gentile F, Vingolo EM, Gasparini P, Banfi S. A nove GJA1 mutation causes oculodentodigital dysplasia without syndactyly. Am J Med Genet A. 2005;133A(1):58-60.

81. Richardson RJ, Joss S, Tomkin S, Ahmed M, Sheridan E, Dixon MJ. A nonsense mutation in the first transmembrane domain of connexin 43 underlies autosomal recessive oculodentodigital syndrome. J Med Genet. 2006;43(7):e37.

82. Loddenkemper T, Grote K, Evers S, Oelerich M, Stogbauer F. Neurological manifestations of the oculodentodigital dysplasia syndrome. J Neurol. 2002; 249(5):584-95.

83. McLachlan E, Plante I, Shao Q, Tong D, Kidder GM, Bernier SM, Laird DW. ODDD-linked Cx43 mutants reduce endogenous Cx43 expression and function in osteoblasts and inhibit late stage differentiation. J Bone Miner Res. 2008:23(6):928-38.

84. Laird DW. Connexin phosphorylation as a regulatory event linked to gap junction internalization and degradation. Biochim Biophys Acta. 2005: 1711(2):172-82.

85. Giepmans BN, Verlaan I, Moolenaar WH. Connexin-43 interactions with ZO-1 and alpha- and beta-tubulin. Cell Commun Adhes. 2001;8(4-6):219-23.

86. Kanemitsu MY, Loo LW, Simon S, Lau AF, Eckhart W. Tyrosine phosphorylation of connexin 43 by $\mathrm{v}$-Src is mediated by $\mathrm{SH} 2$ and $\mathrm{SH} 3$ domain interactions. J Biol Chem. 1997;272(36):22824-31.

87. Giepmans BN. Gap junctions and connexin-interacting proteins. Cardiovasc Res. 2004;62(2):233-45.

88. Delmar M, Coombs W, Sorgen P, Duffy HS, Taffet SM. Structural bases for the chemical regulation of Connexin43 channels. Cardiovasc Res. 2004;62(2):268-75

89. Seki A, Coombs W, Taffet SM, Delmar M. Loss of electrical communication, but not plaque formation, after mutations in the cytoplasmic loop of connexin43. Heart Rhythm. 2004;1(2):227-33.

90. Roscoe W, Veitch Gl, Gong XQ, Pellegrino E, Bai D, McLachlan E, Shao Q, Kidder GM, Laird DW. Oculodentodigital dysplasia-causing connexin43 mutants are non-functional and exhibit dominant effects on wild-type connexin43. J Biol Chem. 2005;280(12):11458-66.

91. Dobrowolski R, Sommershof A, Willecke K. Some oculodentodigital dysplasia-associated Cx43 mutations cause increased hemichannel activity in addition to deficient gap junction channels. J Membr Biol. 2007;219(1-3): 9-17.

92. Churko JM, Langlois S, Pan X, Shao Q, Laird DW. The potency of the fs 260 connexin43 mutant to impair keratinocyte differentiation is distinct from other disease-linked connexin43 mutants. Biochem J. 2010;429(3):473-83.

93. Dobrowolski R, Sasse P, Schrickel JW, Watkins M, Kim JS, Rackauskas M, Troatz C, Ghanem A, Tiemann K, Degen J, et al. The conditional connexin43G138R mouse mutant represents a new model of hereditary oculodentodigital dysplasia in humans. Hum Mol Genet. 2008;17(4):539-54.

94. Severs NJ, Bruce AF, Dupont E, Rothery S. Remodelling of gap junctions and connexin expression in diseased myocardium. Cardiovasc Res. 2008;80(1):9-19.

95. Garcia-Dorado D, Rodriguez-Sinovas A, Ruiz-Meana M. Gap junctionmediated spread of cell injury and death during myocardial ischemiareperfusion. Cardiovasc Res. 2004;61(3):386-401.

96. van Kempen MJ, ten Velde I, Wessels A, Oosthoek PW. Gros D, Jongsma HJ, Moorman AF, Lamers WH. Differential connexin distribution accommodates cardiac function in different species. Microsc Res Tech. 1995;31(5):420-36.

97. Huang GY, Xie LJ, Linask KL, Zhang C, Zhao XQ, Yang Y, Zhou GM, Wu YJ, Marquez-Rosado L, McElhinney DB, et al. Evaluating the role of connexin43 in congenital heart disease: Screening for mutations in patients with outflow tract anomalies and the analysis of knock-in mouse models. J Cardiovasc Dis Res. 2011;2(4):206-12.

98. Britz-Cunningham SH, Shah MM, Zuppan CW, Fletcher WH. Mutations of the Connexin43 gap-junction gene in patients with heart malformations and defects of laterality. N Engl J Med. 1995;332(20):1323-9.

99. Thibodeau IL, Xu J, Li Q, Liu G, Lam K, Veinot JP, Birnie DH, Jones DL, Krahn $A D$, Lemery $R$, et al. Paradigm of genetic mosaicism and lone atrial fibrillation: physiological characterization of a connexin 43-deletion mutant identified from atrial tissue. Circulation. 2010:122(3):236-44.

100. TenBroek EM, Johnson R, Louis CF. Cell-to-cell communication in a differentiating ovine lens culture system. Invest Ophthalmol Vis Sci. 1994; 35(1):215-28.

101. Dahm R. Lens fibre cell differentiation - A link with apoptosis? Ophthalmic Res. 1999;31(3):163-83.

102. Rong P, Wang X, Niesman I, Wu Y, Benedetti LE, Dunia I, Levy E, Gong X Disruption of Gja8 (alpha8 connexin) in mice leads to microphthalmia associated with retardation of lens growth and lens fiber maturation. Development. 2002;129(1):167-74.

103. White TW, Bruzzone R, Goodenough DA, Paul DL. Mouse Cx50, a functional member of the connexin family of gap junction proteins, is the lens fiber protein MP70. Mol Biol Cell. 1992;3(7):711-20.

104. Minogue PJ, Tong JJ, Arora A, Russell-Eggitt I, Hunt DM, Moore AT, Ebihara L, Beyer EC, Berthoud VM. A mutant connexin50 with enhanced hemichannel function leads to cell death. Invest Ophthalmol Vis Sci. 2009; 50(12):5837-45.

105. Xu X, Berthoud VM, Beyer EC, Ebihara L. Functional role of the carboxyl terminal domain of human connexin 50 in gap junctional channels. Membr Biol. 2002;186(2):101-12

106. Tong JJ, Minogue PJ, Guo W, Chen TL, Beyer EC, Berthoud VM, Ebihara L. Different consequences of cataract-associated mutations at adjacent positions in the first extracellular boundary of connexin50. Am J Physiol Cell Physiol. 2011:300(5):C1055-64.

107. Beyer EC, Berthoud VM. Connexin hemichannels in the lens. Front Physiol. 2014;5:20

108. Paul DL, Ebihara L, Takemoto LJ, Swenson Kl, Goodenough DA. Connexin46, a novel lens gap junction protein, induces voltage-gated currents in nonjunctional plasma membrane of Xenopus oocytes. J Cell Biol. 1991; 115(4):1077-89.

109. Jiang JX, Goodenough DA. Heteromeric connexons in lens gap junction channels. Proc Natl Acad Sci U S A. 1996;93(3):1287-91.

110. Rubinos C, Villone K, Mhaske PV, White TW, Srinivas M. Functional effects of Cx50 mutations associated with congenital cataracts. Am J Physiol Cell Physiol. 2014:306(3):C212-20.

111. Gao J, Sun X, Martinez-Wittinghan FJ, Gong X, White TW, Mathias RT. Connections between connexins, calcium, and cataracts in the lens. J Gen Physiol. 2004;124(4):289-300.

112. Mathias RT, White TW, Gong X. Lens gap junctions in growth differentiation, and homeostasis. Physiol Rev. 2010;90(1):179-206.

113. Jara O, Acuna R, Garcia IE, Maripillan J, Figueroa V, Saez JC, Araya-Secchi R, Lagos CF, Perez-Acle T, Berthoud VM, et al. Critical role of the first 
transmembrane domain of $\mathrm{C} \times 26$ in regulating oligomerization and function. Mol Biol Cell. 2012;23(17):3299-311.

114. DeRosa AM, Xia CH, Gong X, White TW. The cataract-inducing S50P mutation in Cx50 dominantly alters the channel gating of wild-type lens connexins. J Cell Sci. 2007;120(Pt 23):4107-16.

115. Bicego M, Beltramello M, Melchionda S, Carella M, Piazza V, Zelante L, Bukauskas FF, Arslan E, Cama E, Pantano S, et al. Pathogenetic role of the deafness-related M34T mutation of Cx26. Hum Mol Genet. 2006;15(17): 2569-87.

116. Banks EA, Toloue MM, Shi Q, Zhou ZJ, Liu J, Nicholson BJ, Jiang JX. Connexin mutation that causes dominant congenital cataracts inhibits gap junctions, but not hemichannels, in a dominant negative manner. J Cell Sci. 2009:122(Pt 3):378-88.

117. Arora A, Minogue PJ, Liu X, Addison PK, Russel-Eggitt I, Webster AR, Hunt DM, Ebihara L, Beyer EC, Berthoud VM, et al. A novel connexin50 mutation associated with congenital nuclear pulverulent cataracts. J Med Genet. 2008; 45(3):155-60.

118. DeRosa AM, Mese G, Li L, Sellitto C, Brink PR, Gong X, White TW. The cataract causing Cx50-S50P mutant inhibits Cx43 and intercellular communication in the lens epithelium. Exp Cell Res. 2009;315(6):1063-75.

119. Sali A, Blundell TL. Comparative protein modelling by satisfaction of spatial restraints. J Mol Biol. 1993;234(3):779-815.

120. Bargiello TA, Tang Q, Oh S, Kwon T. Voltage-dependent conformational changes in connexin channels. Biochim Biophys Acta. 2012;1818(8): 1807-22.

121. Fleishman SJ, Ben-Tal N. Progress in structure prediction of alpha-helical membrane proteins. Curr Opin Struct Biol. 2006;16(4):496-504.

122. Retamal MA, Reyes EP, Garcia IE, Pinto B, Martinez AD, Gonzalez C. Diseases associated with leaky hemichannels. Front Cell Neurosci. 2015;9:267.

123. Lee JR, Derosa AM, White TW. Connexin mutations causing skin disease and deafness increase hemichannel activity and cell death when expressed in Xenopus oocytes. J Invest Dermatol. 2009;129(4):870-8.

124. Gerido DA, DeRosa AM, Richard G, White TW. Aberrant hemichannel properties of $\mathrm{C} \times 26$ mutations causing skin disease and deafness. Am J Physiol Cell Physiol. 2007;293(1):C337-45.

125. Abrams CK, Bennett MV, Verselis VK, Bargiello TA. Voltage opens unopposed gap junction hemichannels formed by a connexin 32 mutant associated with X-linked Charcot-Marie-Tooth disease. Proc Natl Acad Sci U S A. 2002; 99(6):3980-4.

126. Liang GS, de Miguel M, Gomez-Hernandez JM, Glass JD, Scherer SS, Mintz $M$, et al. Severe neuropathy with leaky connexin32 hemichannels. Ann Neurol. 2005;57(5):749-54.

127. Abrams CK, Freidin MM, Verselis VK, Bennett MV, Bargiello TA. Functional alterations in gap junction channels formed by mutant forms of connexin 32: evidence for loss of function as a pathogenic mechanism in the X-linked form of Charcot-Marie-Tooth disease. Brain Res. 2001:900(1):9-25.

128. Abrams CK, Oh S, Ri Y, Bargiello TA. Mutations in connexin 32: the molecular and biophysical bases for the X-linked form of Charcot-MarieTooth disease. Brain Res Brain Res Rev. 2000;32(1):203-14.

129. Kleopa KA, Sargiannidou I. Connexins, gap junctions and peripheral neuropathy. Neurosci Lett. 2015;596:27-32.

130. Sánchez HA, Verselis VK. Aberrant Cx26 hemichannels and keratitisichthyosis-deafness syndrome: insights into syndromic hearing loss. Front Cell Neurosci. 2014:8:354

131. Shuja Z, Li L, Gupta S, Mese G, White TW. Connexin26 Mutations Causing Palmoplantar Keratoderma and Deafness Interact with connexin43, Modifying Gap Junction and Hemichannel Properties. J Invest Dermatol. 2016;136(1):225-35. doi:10.1038/JID.2015.389.

132. Thonnissen E, Rabionet R, Arbones ML, Estivill X, Willecke K, Ott T. Human connexin26 (GJB2) deafness mutations affect the function of gap junction channels at different levels of protein expression. Hum Genet. 2002;111(2): 190-7.

133. Mese G, Londin E, Mui R, Brink PR, White TW. Altered gating properties of functional Cx26 mutants associated with recessive non-syndromic hearing loss. Hum Genet. 2004;115(3):191-9.

134. Chen $Y$, Deng $Y$, Bao X, Reuss L, Altenberg GA. Mechanism of the defect in gap-junctional communication by expression of a connexin 26 mutant associated with dominant deafness. FASEB J. 2005;19(11):1516-8.

135. Wu BL, Lindeman N, Lip V, Adams A, Amato RS, Cox G, Irons M, Kenna M, Korf B, Raisen J, et al. Effectiveness of sequencing connexin 26 (GJB2) in cases of familial or sporadic childhood deafness referred for molecular diagnostic testing. Genet Med. 2002;4(4):279-88.

136. Iossa S, Marciano E, Franze A. GJB2 Gene Mutations in Syndromic Skin Diseases with Sensorineural Hearing Loss. Curr Genomics. 2011;12(7):475-785.

137. Terrinoni A, Codispoti A, Serra V, Didona B, Bruno E, Nistico R, Giustizieri M, Alessandrini M, Campione E, Melino G. Connexin 26 (GJB2) mutations, causing KID Syndrome, are associated with cell death due to calcium gating deregulation. Biochem Biophys Res Commun. 2010;394(4):909-14.

138. de Zwart-Storm EA, Rosa RF, Martin PE, Foelster-Holst R, Frank J, Bau AE, Zen PR, Graziadio C, Paskulin GA, Kamps MA, et al. Molecular analysis of connexin26 asparagine14 mutations associated with syndromic skin phenotypes. Exp Dermatol. 2011;20(5):408-12.

139. Haack B, Schmalisch K, Palmada M, Bohmer C, Kohlschmidt N, Keilmann A Zechner U, Limberger A, Beckert S, Zenner HP, et al. Deficient membrane integration of the novel p. N14D-GJB2 mutant associated with nonsyndromic hearing impairment. Hum Mutat. 2006;27(11):1158-9.

140. Choi SY, Lee KY, Kim HJ, Kim HK, Chang Q, Park HJ, Jeon CJ, Lin X, Bok J, Kim UK. Functional evaluation of GJB2 variants in nonsyndromic hearing loss. Mol Med. 2011;17(5-6):550-6.

141. Mani RS, Ganapathy A, Jalvi R, Srikumari Srisailapathy CR, Malhotra V, Chadha S, Agarwal A, Ramesh A, Rangasayee RR, Anand A. Functional consequences of novel connexin 26 mutations associated with hereditary hearing loss. Eur J Hum Genet: EJHG. 2009;17(4):502-9.

142. Martin PE, Coleman SL, Casalotti SO, Forge A, Evans WH. Properties of connexin26 gap junctional proteins derived from mutations associated with non-syndromal heriditary deafness. Hum Mol Genet. 1999;8(13):2369-76.

143. Zhang Y, Tang W, Ahmad S, Sipp JA, Chen P, Lin X. Gap junction-mediated intercellular biochemical coupling in cochlear supporting cells is required for normal cochlear functions. Proc Natl Acad Sci U S A. 2005;102(42): 15201-6.

144. Palmada M, Schmalisch K, Bohmer C, Schug N, Pfister M, Lang F, Blin N. Loss of function mutations of the GJB2 gene detected in patients with DFNB1associated hearing impairment. Neurobiol Dis. 2006;22(1):112-8.

145. Skerrett IM, Di WL, Kasperek EM, Kelsell DP, Nicholson BJ. Aberrant gating, but a normal expression pattern, underlies the recessive phenotype of the deafness mutant Connexin26M34T. FASEB J. 2004;18(7):860-2.

146. White TW, Deans MR, Kelsell DP, Paul DL. Connexin mutations in deafness. Nature. 1998:394(6694):630-1.

147. Bruzzone R, Veronesi V, Gomes D, Bicego M, Duval N, Marlin S, Petit C, D'Andrea P, White TW. Loss-of-function and residual channel activity of connexin26 mutations associated with non-syndromic deafness. FEBS Lett. 2003:533(1-3):79-88.

148. Kenna MA, Wu BL, Cotanche DA, Korf BR, Rehm HL. Connexin 26 studies in patients with sensorineural hearing loss. Arch otolaryngol-head \& neck Surg. 2001;127(9):1037-42.

149. Kim J, Jung J, Lee MG, Choi JY, Lee KA. Non-syndromic hearing loss caused by the dominant cis mutation $\mathrm{R} 75 \mathrm{Q}$ with the recessive mutation V $37 \mathrm{I}$ of the GJB2 (Connexin 26) gene. Exp Mol Med. 2015;47:e169.

150. Sánchez HA, Mese G, Srinivas M, White TW, Verselis VK. Differentially altered $\mathrm{Ca} 2+$ regulation and $\mathrm{Ca} 2+$ permeability in $\mathrm{C} \times 26$ hemichannels formed by the A40V and G45E mutations that cause keratitis ichthyosis deafness syndrome. J Gen Physiol. 2010;136(1):47-62.

151. Sánchez HA, Bienkowski R, Slavi N, Srinivas M, Verselis VK. Altered inhibition of $\mathrm{C} \times 26$ hemichannels by $\mathrm{pH}$ and $\mathrm{Zn} 2+$ in the A40V mutation associated with keratitis-ichthyosis-deafness syndrome. J Biol Chem. 2014;289(31): 21519-32.

152. Zhang J, Scherer SS, Yum SW. Dominant Cx26 mutants associated with hearing loss have dominant-negative effects on wild type CX26. Mol Cell Neurosci. 2011;47(2):71-8.

153. Yum SW, Zhang J, Scherer SS. Dominant connexin26 mutants associated with human hearing loss have trans-dominant effects on connexin30. Neurobiol Dis. 2010;38(2):226-36.

154. Marziano NK, Casalotti SO, Portelli AE, Becker DL, Forge A. Mutations in the gene for connexin 26 (GJB2) that cause hearing loss have a dominant negative effect on connexin 30. Hum Mol Genet. 2003;12(8): 805-12.

155. Bakirtzis G, Choudhry R, Aasen T, Shore L, Brown K, Bryson S, Forrow S, Tetley L, Finbow M, Greenhalgh D, et al. Targeted epidermal expression of mutant Connexin 26(D66H) mimics true Vohwinkel syndrome and provides a model for the pathogenesis of dominant connexin disorders. Hum Mol Genet. 2003;12(14):1737-44. 
156. Thomas T, Jordan K, Simek J, Shao Q, Jedeszko C, Walton P, Laird DW. Mechanisms of Cx43 and Cx26 transport to the plasma membrane and gap junction regeneration. J Cell Sci. 2005;118(Pt 19):4451-62.

157. Thomas T, Telford D, Laird DW. Functional domain mapping and selective trans-dominant effects exhibited by Cx26 disease-causing mutations. J Biol Chem. 2004;279(18):19157-68.

158. Thomas T, Aasen T, Hodgins M, Laird DW. Transport and function of cx26 mutants involved in skin and deafness disorders. Cell Commun Adhes. 2003; 10(4-6):353-8.

159. Rouan F, White TW, Brown N, Taylor AM, Lucke TW, Paul DL, Munro CS, Uitto J, Hodgins MB, Richard G. Trans-dominant inhibition of connexin-43 by mutant connexin-26: implications for dominant connexin disorders affecting epidermal differentiation. J Cell Sci. 2001;114(Pt 11):2105-13.

160. Choi SY, Park HJ, Lee KY, Dinh EH, Chang Q, Ahmad S, Lee SH, Bok J, Lin X, Kim UK. Different functional consequences of two missense mutations in the GJB2 gene associated with non-syndromic hearing loss. Hum Mutat. 2009;30(7):E716-27.

161. Bruzzone R, Gomes D, Denoyelle E, Duval N, Perea J, Veronesi V, Weil D, Petit C, Gabellec MM, D'Andrea P, et al. Functional analysis of a dominant mutation of human connexin26 associated with nonsyndromic deafness. Cell Commun Adhes. 2001:8(4-6):425-31.

162. Melchionda S, Bicego M, Marciano E, Franze A, Morgutti M, Bortone G, Zelante L, Carella M, D'Andrea P. Functional characterization of a novel Cx26 (T55N) mutation associated to non-syndromic hearing loss. Biochem Biophys Res Commun. 2005;337(3):799-805.

163. Tekin M, Arnos KS, Xia XJ, Oelrich MK, Liu XZ, Nance WE, Pandya A. W44C mutation in the connexin 26 gene associated with dominant nonsyndromic deafness. Clin Genet. 2001;59(4):269-73.

164. Stong BC, Chang Q, Ahmad S, Lin X. A novel mechanism for connexin 26 mutation linked deafness: cell death caused by leaky gap junction hemichannels. Laryngoscope. 2006;116(12):2205-10.

165. Ogawa Y, Takeichi T, Kono M, Hamajima N, Yamamoto T, Sugiura K, Akiyama M. Revertant mutation releases confined lethal mutation, opening Pandora's box: a novel genetic pathogenesis. PLoS Genet. 2014;10(5): e1004276.

166. Oguchi T, Ohtsuka A, Hashimoto S, Oshima A, Abe S, Kobayashi Y, Nagai K, Matsunaga T, Iwasaki S, Nakagawa T, et al. Clinical features of patients with GJB2 (connexin 26) mutations: severity of hearing loss is correlated with genotypes and protein expression patterns. J Hum Genet. 2005;50(2):76-83.

167. Prasad S, Cucci RA, Green GE, Smith RJ. Genetic testing for hereditary hearing loss: connexin 26 (GJB2) allele variants and two novel deafness-causing mutations (R32C and 645-648delTAGA). Hum Mutat. 2000;16(6):502-8.

168. Mhaske PV, Levit NA, Li L, Wang HZ, Lee JR, Shuja Z, Brink PR, White TW. The human Cx26-D50A and Cx26-A88V mutations causing keratitisichthyosis-deafness syndrome display increased hemichannel activity. Am J Physiol Cell Physiol. 2013;304(12):C1150-8.

169. Cushing SL, MacDonald L, Propst EJ, Sharma A, Stockley T, Blaser SL, James $A L$, Papsin BC. Successful cochlear implantation in a child with Keratosis, Icthiosis and Deafness (KID) Syndrome and Dandy-Walker malformation. Int J Pediatr Otorhinolaryngol. 2008;72(5):693-8.

170. Lopez W, Gonzalez J, Liu Y, Harris AL, Contreras JE. Insights on the mechanisms of $\mathrm{Ca}(2+)$ regulation of connexin 26 hemichannels revealed by human pathogenic mutations (D50N/Y). J Gen Physiol. 2013;142(1):23-35.

171. Terrinoni A, Codispoti A, Serra V, Bruno E, Didona B, Paradisi M, Nistico S, Campione E, Napolitano B, Diluvio L, et al. Connexin 26 (GJB2) mutations as a cause of the KID syndrome with hearing loss. Biochem Biophys Res Commun. 2010;395(1):25-30

172. Sánchez HA, Villone K, Srinivas M, Verselis VK. The D50N mutation and syndromic deafness: altered Cx26 hemichannel properties caused by effects on the pore and intersubunit interactions. J Gen Physiol. 2013; 142(1):3-22

173. Toth T, Kupka S, Haack B, Riemann K, Braun S, Fazakas F, Zenner HP, Muszbek L, Blin N, Pfister M, et al. GJB2 mutations in patients with non-syndromic hearing loss from Northeastern Hungary. Hum Mutat. 2004;23(6):631-2.

174. Piazza V, Beltramello M, Menniti M, Colao E, Malatesta P, Argento R, Chiarella G, Gallo LV, Catalano M, Perrotti N, et al. Functional analysis of R75Q mutation in the gene coding for Connexin 26 identified in a family with nonsyndromic hearing loss. Clin Genet. 2005;68(2):161-6.

175. Bajaj Y, Sirimanna T, Albert DM, Qadir P, Jenkins L, Bitner-Glindzicz M. Spectrum of GJB2 mutations causing deafness in the British Bangladeshi population. Clin Otolaryngol. 2008;33(4):313-8.
176. Carrasquillo MM, Zlotogora J, Barges S, Chakravarti A. Two different connexin 26 mutations in an inbred kindred segregating non-syndromic recessive deafness: implications for genetic studies in isolated populations. Hum Mol Genet. 1997;6(12):2163-72.

177. Kupka S, Braun S, Aberle S, Haack B, Ebauer M, Zeissler U, Zenner HP, Blin N, Pfister M. Frequencies of GJB2 mutations in German control individuals and patients showing sporadic non-syndromic hearing impairment. Hum Mutat. 2002;20(1):77-8

178. Wang HL, Chang WT, Li AH, Yeh TH, Wu CY, Chen MS, Huang PC. Functional analysis of connexin-26 mutants associated with hereditary recessive deafness. J Neurochem. 2003;84(4):735-42.

179. Ambrosi C, Boassa D, Pranskevich J, Smock A, Oshima A, Xu J, Nicholson BJ, Sosinsky GE. Analysis of four connexin 26 mutant gap junctions and hemichannels reveals variations in hexamer stability. Biophys J. 2010;98(9): 1809-19.

180. Cryns K, Orzan E, Murgia A, Huygen PL, Moreno F, del Castillo I, Chamberlin GP, Azaiez H, Prasad S, Cucci RA, et al. A genotypephenotype correlation for GJB2 (connexin 26) deafness. J Med Genet. 2004:41(3):147-54

181. Meigh L, Hussain N, Mulkey DK, Dale N. Connexin26 hemichannels with a mutation that causes KID syndrome in humans lack sensitivity to CO2. Elife. 2014;3:e04249.

182. Posukh O, Pallares-Ruiz N, Tadinova V, Osipova L, Claustres M, Roux AF. First molecular screening of deafness in the Altai Republic population. BMC Med Genet. 2005;6:12.

183. Loffler J, Nekahm D, Hirst-Stadlmann A, Gunther B, Menzel HJ, Utermann G, Janecke AR. Sensorineural hearing loss and the incidence of $C \times 26$ mutations in Austria. Eur J Hum Genet. 2001;9(3):226-30.

184. Marlin S, Garabedian EN, Roger G, Moatti L, Matha N, Lewin P, Petit C, Denoyelle F. Connexin 26 gene mutations in congenitally deaf children: pitfalls for genetic counseling. Arch Otolaryngol Head Neck Surg. 2001; 127(8):927-33.

185. Man YK, Trolove C, Tattersall D, Thomas AC, Papakonstantinopoulou A, Patel $D$, et al. A deafness-associated mutant human connexin 26 improves the epithelial barrier in vitro. J Membr Biol. 2007;218(1-3):29-37.

186. Brobby GW, Muller-Myhsok B, Horstmann RD. Connexin 26 R143W mutation associated with recessive nonsyndromic sensorineural deafness in Africa. N Engl J Med. 1998;338(8):548-50.

187. Xiao Z, Yang Z, Liu X, Xie D. Impaired membrane targeting and aberrant cellular localization of human Cx26 mutants associated with inherited recessive hearing loss. Acta Otolaryngol. 2011;131(1):59-66.

188. Rickard S, Kelsell DP, Sirimana T, Rajput K, MacArdle B, Bitner-Glindzicz M. Recurrent mutations in the deafness gene GJB2 (connexin 26) in British Asian families. J Med Genet. 2001;38(8):530-3.

189. Denoyelle F, Weil D, Maw MA, Wilcox SA, Lench NJ, Allen-Powell DR, Osborn AH, Dahl HH, Middleton A, Houseman MJ, et al. Prelingual deafness: high prevalence of a 30delG mutation in the connexin 26 gene. Hum Mol Genet. 1997;6(12):2173-7.

190. Hamelmann C, Amedofu GK, Albrecht K, Muntau B, Gelhaus A, Brobby GW, Horstmann RD. Pattern of connexin 26 (GJB2) mutations causing sensorineural hearing impairment in Ghana. Hum Mutat. 2001;18(1):84-5.

191. Matos TD, Caria H, Simoes-Teixeira H, Aasen T, Dias O, Andrea M, Kelsell DP, Fialho G. A novel M163L mutation in connexin 26 causing cell death and associated with autosomal dominant hearing loss. Hear Res. 2008;240(1-2): 87-92.

192. de Zwart-Storm EA, van Geel M, van Neer PA, Steijlen PM, Martin PE, van Steensel MA. A novel missense mutation in the second extracellular domain of GJB2, p. Ser183Phe, causes a syndrome of focal palmoplantar keratoderma with deafness. Am J Pathol. 2008; 173(4):1113-9.

193. Ambrosi C, Walker AE, Depriest AD, Cone AC, Lu C, Badger J, Skerrett IM, Sosinsky GE. Analysis of trafficking, stability and function of human connexin 26 gap junction channels with deafness-causing mutations in the fourth transmembrane helix. PLoS One. 2013;8(8):e70916.

194. Mese G, Valiunas V, Brink PR, White TW. Connexin26 deafness associated mutations show altered permeability to large cationic molecules. Am J Physiol Cell Physiol. 2008;295(4):C966-74.

195. Morle L, Bozon M, Alloisio N, Latour P, Vandenberghe A, Plauchu H, Collet L, Edery P, Godet J, Lina-Granade G. A novel C202F mutation in the connexin26 gene (GJB2) associated with autosomal dominant isolated hearing loss. J Med Genet. 2000;37(5):368-70. 
196. Yilmaz A, Menevse S, Bayazit Y, Karamert R, Ergin V, Menevse A. Two nove missense mutations in the connexin 26 gene in Turkish patients with nonsyndromic hearing loss. Biochem Genet. 2010;48(3-4):248-56.

197. Deschenes SM, Walcott JL, Wexler TL, Scherer SS, Fischbeck KH. Altered trafficking of mutant connexin32. J neurosci: J Soc Neurosci. 1997;17(23): 9077-84.

198. Ionasescu V, Ionasescu R, Searby C. Correlation between connexin 32 gene mutations and clinical phenotype in X-linked dominant Charcot-MarieTooth neuropathy. Am J Med Genet. 1996;63(3):486-91.

199. Fryns JP, Van den Berghe $H$. Sex-linked recessive inheritance in CharcotMarie-tooth disease with partial clinical manifestations in female carriers. Hum Genet. 1980;55(3):413-5.

200. Gutierrez A, England JD, Sumner AJ, Ferer S, Warner LE, Lupski JR, Garcia CA Unusual electrophysiological findings in X-linked dominant Charcot-MarieTooth disease. Muscle Nerve. 2000;23(2):182-8.

201. Senderek J, Hermanns B, Bergmann C, Boroojerdi B, Bajbouj M, Hungs M, Ramaekers VT, Quasthoff S, Karch D, Schroder JM. X-linked dominant Charcot-Marie-Tooth neuropathy: clinical, electrophysiological, and morphological phenotype in four families with different connexin32 mutations(1). J Neurol Sci. 1999;167(2):90-101.

202. Martin PE, Mambetisaeva ET, Archer DA, George CH, Evans WH. Analysis of gap junction assembly using mutated connexins detected in Charcot-MarieTooth X-linked disease. J Neurochem. 2000;74(2):711-20.

203. Wang HL, Chang WT, Yeh TH, Wu T, Chen MS, Wu CY. Functional analysis of connexin-32 mutants associated with X-linked dominant Charcot-MarieTooth disease. Neurobiol Dis. 2004;15(2):361-70.

204. Kleopa KA, Yum SW, Scherer SS. Cellular mechanisms of connexin32 mutations associated with CNS manifestations. J Neurosci Res. 2002;68(5): 522-34.

205. Yum SW, Kleopa KA, Shumas S, Scherer SS. Diverse trafficking abnormalities of connexin32 mutants causing CMTX. Neurobiol Dis. 2002;11(1):43-52.

206. Dubourg O, Tardieu S, Birouk N, Gouider R, Leger JM, Maisonobe T, Brice A, Bouche P, LeGuern E. Clinical, electrophysiological and molecular genetic characteristics of 93 patients with X-linked Charcot-Marie-Tooth disease. Brain. 2001;124(Pt 10):1958-67.

207. Zhang Y, Hao H. Conserved glycine at position 45 of major cochlear connexins constitutes a vital component of the $\mathrm{Ca}(2)(+)$ sensor for gating of gap junction hemichannels. Biochem Biophys Res Commun. 2013;436(3):424-9.

208. Yoshimura T, Satake M, Ohnishi A, Tsutsumi Y, Fujikura Y. Mutations of connexin32 in Charcot-Marie-Tooth disease type $X$ interfere with cell-to-cell communication but not cell proliferation and myelin-specific gene expression. J Neurosci Res. 1998;51(2):154-61.

209. Omori Y, Mesnil M, Yamasaki H. Connexin 32 mutations from X-linked Charcot-Marie-Tooth disease patients: functional defects and dominant negative effects. Mol Biol Cell. 1996;7(6):907-16.

210. Abrams CK, Islam M, Mahmoud R, Kwon T, Bargiello TA, Freidin MM. Functional requirement for a highly conserved charged residue at position 75 in the gap junction protein connexin 32. J Biol Chem. 2013;288(5):3609-19.

211. Janssen EA, Kemp S, Hensels GW, Sie OG, de Die-Smulders CE, Hoogendijk $\mathrm{JE}$, et al. Connexin32 gene mutations in X-linked dominant Charcot-MarieTooth disease (CMTX1). Hum Genet. 1997;99(4):501-5.

212. Ri Y, Ballesteros JA, Abrams CK, Oh S, Verselis VK, Weinstein H, Bargiello TA. The role of a conserved proline residue in mediating conformational changes associated with voltage gating of $\mathrm{C} \times 32$ gap junctions. Biophys J. 1999;76(6):2887-98.

213. Abrams CK, Freidin M, Bukauskas F, Dobrenis K, Bargiello TA, Verselis VK, Bennett MV, Chen L, Sahenk Z. Pathogenesis of X-linked Charcot-MarieTooth disease: differential effects of two mutations in connexin 32. J neurosci: j Soc Neurosci. 2003;23(33):10548-58.

214. Stauch K, Kieken F, Sorgen P. Characterization of the structure and intermolecular interactions between the connexin 32 carboxyl-terminal domain and the protein partners synapse-associated protein 97 and calmodulin. J Biol Chem. 2012;287(33):27771-88.

215. Jeng $\sqcup$, Balice-Gordon RJ, Messing A, Fischbeck KH, Scherer SS. The effects of a dominant connexin32 mutant in myelinating Schwann cells. Mol Cell Neurosci. 2006;32(3):283-98.

216. VanSlyke JK, Deschenes SM, Musil LS. Intracellular transport, assembly, and degradation of wild-type and disease-linked mutant gap junction proteins Mol Biol Cell. 2000;11(6):1933-46.
217. Fairweather N, Bell C, Cochrane S, Chelly J, Wang S, Mostacciuolo ML, Monaco AP, Haites NE. Mutations in the connexin 32 gene in X-linked dominant Charcot-Marie-Tooth disease (CMTX1). Hum Mol Genet. 1994;3(1): 29-34.

218. Kleopa KA, Zamba-Papanicolaou E, Alevra X, Nicolaou P, Georgiou DM, Hadjisavvas A, Kyriakides T, Christodoulou K. Phenotypic and cellular expression of two novel connexin32 mutations causing CMT1X. Neurology. 2006;66(3):396-402.

219. Bruzzone R, White TW, Scherer SS, Fischbeck KH, Paul DL. Null mutations of connexin32 in patients with X-linked Charcot-Marie-Tooth disease. Neuron. 1994;13(5):1253-60.

220. Castro C, Gomez-Hernandez JM, Silander K, Barrio LC. Altered formation of hemichannels and gap junction channels caused by C-terminal connexin-32 mutations. J Neurosci. 1999;19(10):3752-60.

221. Barrio LC, Castro C, Gomez-Hernandez JM. Altered assembly of gap junction channels caused by $\mathrm{COOH}$-terminal connexin32 mutants of CMTX. Ann N Y Acad Sci. 1999;883:526-9.

222. Hahn AF, Brown WF, Koopman WJ, Feasby TE. X-linked dominant hereditary motor and sensory neuropathy. Brain. 1990;113(Pt 5):1511-25.

223. Shao Q, Liu Q, Lorentz R, Gong XQ, Bai D, Shaw GS, Laird DW. Structure and functional studies of N-terminal Cx43 mutants linked to oculodentodigital dysplasia. Mol Biol Cell. 2012;23(17):3312-21.

224. de la Parra DR, Zenteno JC. A new GJA1 (connexin 43) mutation causing oculodentodigital dysplasia associated to uncommon features. Ophthalmic Genet. 2007;28(4):198-202.

225. Kelly SC, Ratajczak P, Keller M, Purcell SM, Griffin T, Richard G. A novel GJA 1 mutation in oculo-dento-digital dysplasia with curly hair and hyperkeratosis. Eur J Dermatol. 2006;16(3):241-5.

226. Shibayama J, Paznekas W, Seki A, Taffet S, Jabs EW, Delmar M, Musa H. Functional characterization of connexin43 mutations found in patients with oculodentodigital dysplasia. Circ Res. 2005;96(10):e83-91.

227. Lai A, Le DN, Paznekas WA, Gifford WD, Jabs EW, Charles AC. Oculodentodigital dysplasia connexin43 mutations result in non-functional connexin hemichannels and gap junctions in C6 glioma cells. J Cell Sci. 2006;119(Pt 3):532-41.

228. Paznekas WA, Karczeski B, Vermeer S, Lowry RB, Delatycki M, Laurence F, Koivisto PA, Van Maldergem L, Boyadjiev SA, Bodurtha JN, et al. GJA1 mutations, variants, and connexin 43 dysfunction as it relates to the oculodentodigital dysplasia phenotype. Hum Mutat. 2009;30(5):724-33.

229. Richardson R, Donnai D, Meire F, Dixon MJ. Expression of Gja1 correlates with the phenotype observed in oculodentodigital syndrome/type III syndactyly. J Med Genet. 2004;41(1):60-7.

230. Huang T, Shao Q, MacDonald A, Xin L, Lorentz R, Bai D, Laird DW Autosomal recessive GJA1 (Cx43) gene mutations cause oculodentodigital dysplasia by distinct mechanisms. J Cell Sci. 2013;126(Pt 13):2857-66.

231. MCLachlan E, Manias JL, Gong XQ, Lounsbury CS, Shao Q, Bernier SM, Bai D, Laird DW. Functional characterization of oculodentodigital dysplasiaassociated Cx43 mutants. Cell Commun Adhes. 2005;12(5-6):279-92.

232. Van Norstrand DW, Asimaki A, Rubinos C, Dolmatova E, Srinivas M, Tester DJ, Saffitz JE, Duffy HS, Ackerman MJ. Connexin43 mutation causes heterogeneous gap junction loss and sudden infant death. Circulation. 2012;125(3):474-81.

233. Van Norstrand DW, Asimaki A, Rubinos C, Dolmatova E, Srinivas M, Tester DJ, Saffitz JE, Duffy HS, Ackerman MJ. The connexin 40 A96S mutation causes renin-dependent hypertension. J Am Soc Nephrol. 2011;22(6):1031-40

234. Kalcheva N, Qu J, Sandeep N, Garcia L, Zhang J, Wang Z, Lampe PD, Suadicani SO, Spray DC, Fishman Gl. Gap junction remodeling and cardiac arrhythmogenesis in a murine model of oculodentodigital dysplasia. Proc Natl Acad Sci U S A. 2007;104(51):20512-6.

235. Hong HM, Yang JJ, Shieh JC, Lin ML, Li SY. Novel mutations in the connexin43 (GJA1) and GJA1 pseudogene may contribute to nonsyndromic hearing loss. Hum Genet. 2010;127(5):545-51.

236. Pizzuti A, Flex E, Mingarelli R, Salpietro C, Zelante L, Dallapiccola B. A homozygous GJA1 gene mutation causes a Hallermann-Streiff/ODDD spectrum phenotype. Hum Mutat. 2004:23(3):286.

237. Beahm DL, Oshima A, Gaietta GM, Hand GM, Smock AE, Zucker SN, Toloue MM, Chandrasekhar A, Nicholson BJ, Sosinsky GE. Mutation of a conserved threonine in the third transmembrane helix of alpha- and beta-connexins creates a dominant-negative closed gap junction channel. J Biol Chem. 2006;281(12):7994-8009. 
238. Zucker SN, Bancroft TA, Place DE, Des Soye B, Bagati A, Berezney R. A dominant negative $\mathrm{C} \times 43$ mutant differentially affects tumorigenic and invasive properties in human metastatic melanoma cells. J Cell Physiol. 2013;228(4):853-9.

239. van Es RJ, Wittebol-Post D, Beemer FA. Oculodentodigital dysplasia with mandibular retrognathism and absence of syndactyly: a case report with a novel mutation in the connexin 43 gene. Int J Oral Maxillofac Surg. 2007; 36(9):858-60.

240. Gong XQ, Shao Q, Lounsbury CS, Bai D, Laird DW. Functional characterization of a GJA1 frameshift mutation causing oculodentodigital dysplasia and palmoplantar keratoderma. J Biol Chem. 2006;281(42):31801-11.

241. Dasgupta C, Martinez AM, Zuppan CW, Shah MM, Bailey LL, Fletcher WH. Identification of connexin43 (alpha1) gap junction gene mutations in patients with hypoplastic left heart syndrome by denaturing gradient gel electrophoresis (DGGE). Mutat Res. 2001:479(1-2):173-86.

242. Thomas BC, Minogue PJ, Valiunas V, Kanaporis G, Brink PR, Berthoud VM, Beyer EC. Cataracts are caused by alterations of a critical N-terminal positive charge in connexin50. Invest Ophthalmol Vis Sci. 2008;49(6):2549-56.

243. Zhu Y, Yu H, Wang W, Gong X, Yao K. Correction: A Novel GJA8 Mutation (p.V44A) Causing Autosomal Dominant Congenital Cataract. PLoS One. 2015;10:e0125949.

244. Vanita V, Singh JR, Singh D, Varon R, Sperling K. A novel mutation in GJA8 associated with jellyfish-like cataract in a family of Indian origin. Mol Vis. 2008;14:323-6

245. Berry V, Mackay D, Khaliq S, Francis PJ, Hameed A, Anwar K, Mehdi SQ, Newbold RJ, lonides A, Shiels A, et al. Connexin 50 mutation in a family with congenital "zonular nuclear" pulverulent cataract of Pakistani origin. Hum Genet. 1999;105(1-2):168-70.

246. Pal JD, Berthoud VM, Beyer EC, Mackay D, Shiels A, Ebihara L. Molecular mechanism underlying a Cx50-linked congenital cataract. Am J Phys. 1999; 276(6 Pt 1):C1443-6

247. Arora A, Minogue PJ, Liu X, Reddy MA, Ainsworth JR, Bhattacharya SS, Webster AR, Hunt DM, Ebihara L, Moore AT, et al. A novel GJA8 mutation is associated with autosomal dominant lamellar pulverulent cataract: further evidence for gap junction dysfunction in human cataract. J Med Genet. 2006;43(1):e2.

248. Liu Y, Qiao C, Wei T, Zheng F, Guo S, Chen Q, et al. Mutant connexin 50 (S276F) inhibits channel and hemichannel functions inducing cataract. J Genet. 2015;94(2):221-9.

249. Yan M, Xiong C, Ye SQ, Chen Y, Ke M, Zheng F, Zhou X. A novel connexin 50 (GJA8) mutation in a Chinese family with a dominant congenital pulverulent nuclear cataract. Mol Vis. 2008;14:418-24.

250. Minogue PJ, Beyer EC, Berthoud VM. A connexin50 mutant, CX50fs, that causes cataracts is unstable, but is rescued by a proteasomal inhibitor. J Biol Chem. 2013;288(28):20427-34.

\section{Submit your next manuscript to BioMed Central and we will help you at every step:}

- We accept pre-submission inquiries

- Our selector tool helps you to find the most relevant journal

- We provide round the clock customer support

- Convenient online submission

- Thorough peer review

- Inclusion in PubMed and all major indexing services

- Maximum visibility for your research

Submit your manuscript at www.biomedcentral.com/submit
Biomed Central 